\begin{tabular}{|c|l|}
\hline Title & Hyperbranched 5,6-glucan as reducing sugar ball \\
\hline Author(s) & $\begin{array}{l}\text { Tamaki, Masaki; Taguchi, Tsukasa; Nakabay ashi, Soichi; Mori, Kota; Kitajyo, Y oshikazu; Sakai, Ryosuke; Kakuchi, } \\
\text { Toyoji; Satoh, Toshifumi }\end{array}$ \\
\hline Citation & $\begin{array}{l}\text { Polymer Chemistry, 1(1), 82-92 } \\
\text { https://doi.org/10.1039/09py00223e }\end{array}$ \\
\hline Issue Date & 2010-03 \\
\hline Doc URL & http://hdl.handle.net/2115/44902 \\
\hline Rights & Polym. Chem., 2010, 1, 82-92-Reproduced by permission of The Royal Society of Chemistry \\
\hline Type & article (author version) \\
\hline File Information & PC1-1_82-92.pdf \\
\hline
\end{tabular}

Instructions for use 


\title{
Hyperbranched 5,6-glucan as reducing sugar ball
}

\author{
Masaki Tamaki, Tsukasa Taguchi, Soichi Nakabayashi, Kota Mori, Yoshikazu Kitajyo, Ryosuke \\ Sakai, Toyoji Kakuchi, and Toshifumi Satoh*
}

Division of Biotechnology and Macromolecular Chemistry, Graduate School of Engineering, Hokkaido University, Sapporo 060-8628, Japan

E-mail: satoh@poly-bm.eng.hokudai.ac.jp, Tel: +81-11-706-6603

*To whom correspondence should be addressed.

\section{Graphical contents entry}

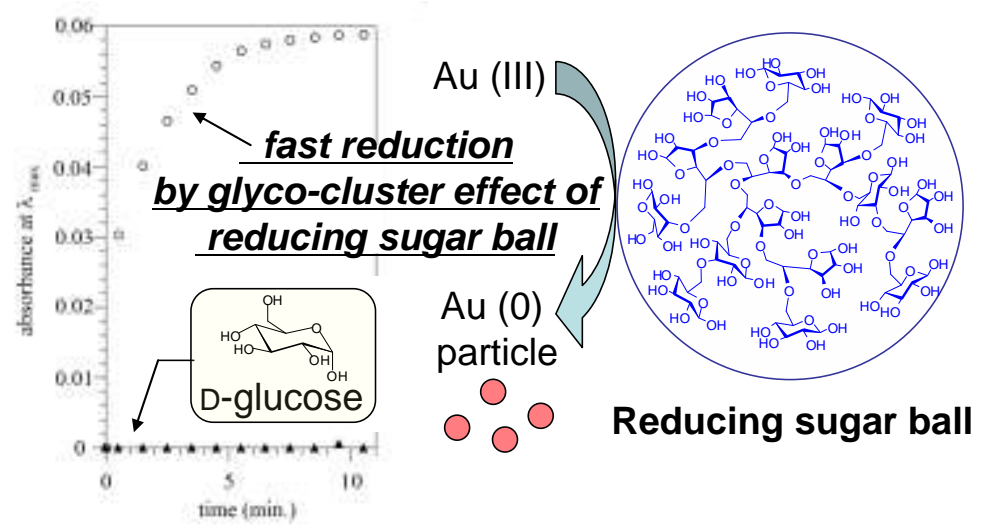

A hyperbranched glycopolymer arranged with numerous reducing D-glucose units on the peripheries of the polymer, i.e., "reducing sugar ball", possessed a higher reducing ability than D-glucose because of the glyco-cluster effect or the multivalent effect of the D-glucose units. 
Abstract. The ring-opening polymerization of 5,6-anhydro-1,2-O-isopropylidene- $\alpha$-D-glucofuranose (1) as a latent cyclic $\mathrm{AB}_{2}$-type monomer was carried out using potassium tert-butoxide $(t$-BuOK) or boron trifluoride diethyletherate $\left(\mathrm{BF}_{3} \cdot \mathrm{OEt}_{2}\right)$ as an initiator in order to synthesize a novel hyperbranched glycopolymer. The anionic and cationic polymerizations proceeded via the proton-transfer reaction mechanism to produce the hyperbranched poly(5,6-anhydro-1,2- $O$-isopropylidene- $\alpha$-D-glucofuranose) (2). In particular, the cationic polymerization with the slow-monomer-addition strategy is a facile method leading to the hyperbranched glycopolymers with high molecular weights and highly branched structures. The weight-average molecular weight ( $\left.M_{\mathrm{w}, \text { SEC-MALLS }}\right)$ values of $\mathbf{2}$ measured by multi-angle laser light scattering (MALLS) varied in the range from 7,400 to 122,400 , which were significantly higher than the weight-average molecular weight $\left(M_{\mathrm{w}, \mathrm{SEC}}\right)$ values determined by size exclusion chromatography (SEC). The intrinsic viscosities $([\eta])$ of these polymers were very low in the range of 3.3-4.6 $\mathrm{mL} \cdot \mathrm{g}^{-1}$ and the Mark-Houwink-Sakurada exponents $\alpha$ were calculated to be $0.08-0.27$. These results of the MALLS, SEC, and viscosity measurements suggested that these polymers exist in a compact spherical conformation in solution because of their highly branched structure. The synthesis of the hyperbranched 5,6-glucan (3) by hydrolysis of polymer 2 was also demonstrated. Polymer $\mathbf{3}$ is a novel water-soluble hyperbranched glycopolymer arranged with numerous reducing D-glucose units on the peripheries of the polymer, and has a higher reducing ability than D-glucose because of the glycocluster effect or the multivalent effect of the reducing D-glucose units. Therefore, polymer $\mathbf{3}$ should be called a "reducing sugar ball".

\section{Introduction}

The spherical architectures of highly branched macromolecules, such as dendrimers, star-shaped polymers, and hyperbranched polymers, have attracted much attention from the viewpoint of nanotechnology, because their numerous terminal units can be converted into various functional groups leading to novel nanomaterials. ${ }^{1-32}$ Thus, various types of dendrimers, star polymers, and hyperbranched polymers have been synthesized and their properties were compared to the linear analogues. ${ }^{23,33-46}$ 
Spherical macromolecular architectures with their surfaces covered with sugars are of increasing interest due to their unique structures along with specific properties, such as the glycol-cluster or multivalent effect on the carbohydrate-protein interactions. For a spherical polymer with many terminal sugar residues, there are a few types of glycodendrimers, e.g., dendrimers prepared from the reaction of the dendrimer surface with mono- and disaccharides (sugar ball), ${ }^{47-59}$ and dendrimers prepared through the convergent method using semi-dendritic branched oligosaccharides. ${ }^{60-64}$ Although the synthesis of such glycodendrimer types was accomplished, dendrimers essentially consisting of sugar units, i.e., dendritic carbohydrate polymers, have not been prepared until now due to the complicated and timeconsuming synthetic process involving numerous protection, deprotection, and purification procedures. Star-shaped glycopolymers were also prepared using the "core-first" method based on the RAFT polymerization $^{65,66}$ and the "arm-first" method based on the TEMPO-mediated radical polymerization. ${ }^{67-}$ ${ }^{70}$ Hyperbranched glycopolymers from the polymerization of $\mathrm{AB}_{\mathrm{m}}$-type monomers can be prepared more easily than glycodendrimers and star-shaped glycopolymers. ${ }^{71-76}$ Recently, we proposed that the ringopening multibranching polymerization of anhydro and dianhydro sugars as latent $\mathrm{AB}_{\mathrm{m}}$-type monomers should be a convenient method of synthesizing hyperbranched glycopolymers with a novel spherical macromolecular architecture, ${ }^{77-83}$ for example, the hyperbranched polysaccharides from the cationic polymerization of 1,6-anhydro- $\beta$-D-hexopyranose, the hyperbranched poly(2,5-anhydro-D-glucitol) from 1,2:5,6-dianhydro-D-mannitol, and the hyperbranched polytetritols of 1,4-anhydrotetritol and 2,3anhydrotetritol. For our synthetic strategy of hyperbranched glycopolymers, it is important to elucidate the effect of the structure of the sugar monomers on the ring-opening multibranching polymerization tendency and to clarify the relationship between the structure and properties of the hyperbranched glycopolymers.

In this article, we report the ring-opening multibranching polymerization of 5,6-anhydro-1,2-Oisopropylidene- $\alpha$-D-glucofuranose (1) as a latent cyclic $\mathrm{AB}_{2}$-type monomer using anionic or cationic initiators, as shown in Fig. 1, leading to the hyperbranched poly(5,6-anhydro-1,2- $O$-isopropylidene- $\alpha$-Dglucofuranose) (2). In fact, Uryu et al. previously reported pioneering research on the ring-opening 
polymerization of $1,^{84,85}$ though the polymer structure was insufficiently characterized as well as the solution properties. Therefore, the characteristics of the polymerization, the polymer structure, and the solution characteristics were discussed by the NMR measurements and the size exclusion chromatography (SEC) with a multi-angle laser light scattering (MALLS) detector and a viscosity detector. In addition, the synthesis of a hyperbranched 5,6-glucan (3) by hydrolysis of polymer 2 was demonstrated. Since polymer $\mathbf{3}$ is a novel water-soluble hyperbranched glycopolymer arranged with numerous reducing D-glucose units on the peripheries of the polymer, the reduction property of 3 is discussed from the viewpoint of the physical property as a "reducing sugar ball".

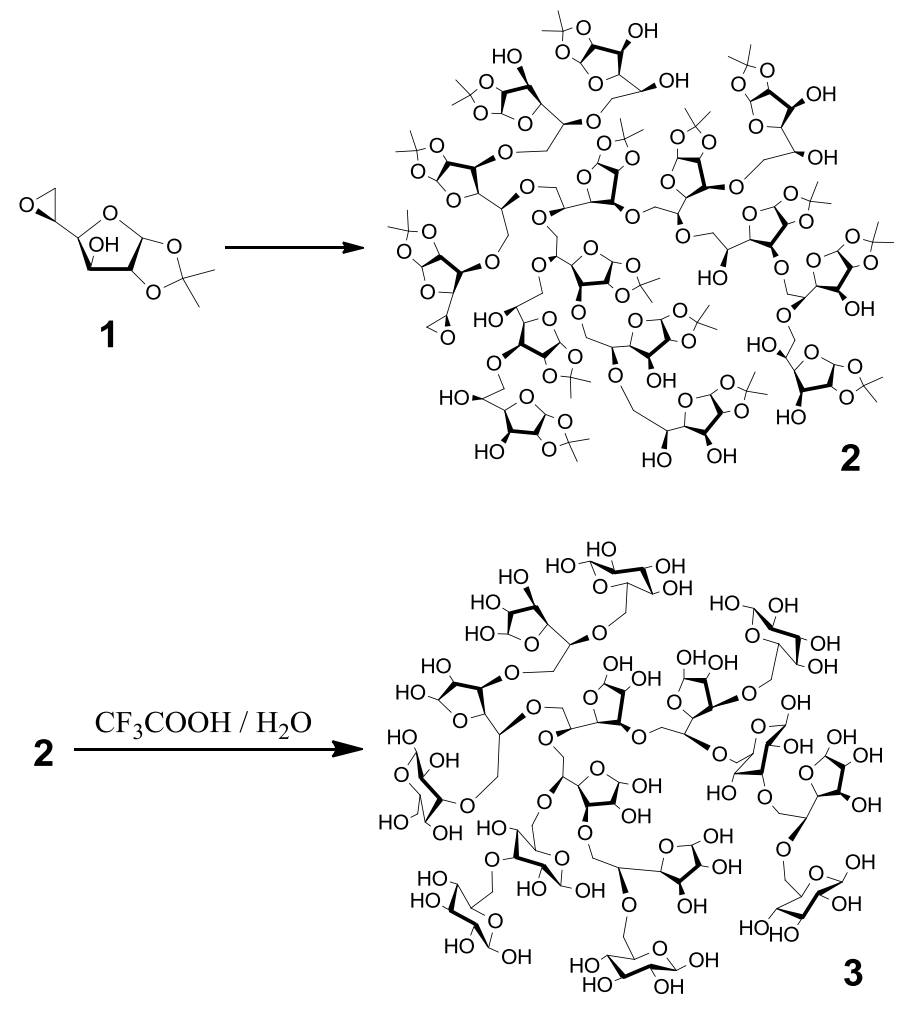

Fig. 1. Polymerization of 5,6-Anhydro-1,2-O-isopropylidene- $\alpha$-D-glucofuranose (1) and synthesis of hyperbranched 5,6-glucan (3) by hydrolysis of polymer 2. 


\section{Experimental}

Materials. 5,6-Anhydro-1,2- $O$-isopropylidene- $\alpha$-D-glucofuranose (1) was synthesized from 1,2-Oisopropylidene- $\alpha$-D-glucofuranose using a procedure similar to that reported by Yus et al. ${ }^{86} \mathbf{1}$ was purified by column chromatography on silica gel with $n$-hexane/ethyl acetate $\left(3 / 2, \mathrm{v} / \mathrm{v}, R_{f}=0.15\right)$ and dried in a vacuum oven at $50{ }^{\circ} \mathrm{C}$ for 2 days. ${ }^{1} \mathrm{H}$ NMR $\left(\mathrm{CDCl}_{3}\right): \delta(\mathrm{ppm}) 1.32$ and $1.48\left(\mathrm{~s}, 6 \mathrm{H}, 2 \mathrm{CH}_{3}\right)$, 2.88 and $3.00(\mathrm{~m}, 2 \mathrm{H}, 2 \mathrm{H}-6), 3.11(\mathrm{~m}, 1 \mathrm{H}, \mathrm{OH}), 3.43(\mathrm{~m}, 1 \mathrm{H}, \mathrm{H}-5), 4.07(\mathrm{~m}, 1 \mathrm{H}, \mathrm{H}-4), 4.26(\mathrm{~m}, 1 \mathrm{H}, \mathrm{H}-$ 3), $4.52(\mathrm{~m}, 1 \mathrm{H}, \mathrm{H}-2), 5.99(\mathrm{~d}, 1 \mathrm{H}, \mathrm{H}-1) .{ }^{13} \mathrm{C} \mathrm{NMR}\left(\mathrm{CDCl}_{3}\right): \delta(\mathrm{ppm}) 26.1$ and $26.7\left(2 \mathrm{C}, 2 \mathrm{CH}_{3}\right), 45.9(\mathrm{C}-$ 6), 50.2 (C-5), 75.1 (C-3), 79.2 (C-4), 85.0 (C-2), 104.9 (C-1), 111.8 (C). Potassium tert-butoxide (t$\mathrm{BuOK})\left(1.0 \mathrm{~mol} \cdot \mathrm{L}^{-1}\right.$ in $\left.\mathrm{THF}\right)$ was obtained from the Sigma-Aldrich Co., and used as received. Boron trifluoride diethyletherate $\left(\mathrm{BF}_{3} \cdot \mathrm{OEt}_{2}\right)$ was purchased from Kanto Chemical Co., Ltd. (Tokyo, Japan) and distilled over $\mathrm{CaH}_{2}$ under reduced pressure. Silica gel 60N (Kanto Chemical Co., Ltd.; spherical shape; particle size, 40-50 $\mu \mathrm{m}$; neutral) was used for the column chromatography. Methyl iodide (>99.5\%), silver oxide $(>99.0 \%)$, an ammonia aqueous solution $(28.0-30.0 \%)$, tetrachloroauric (III) acid $\left(\mathrm{HAuCl}_{4}\right)$ tetrahydrate $(>99.0 \%)$, trifluoroacetic acid $(>99.0 \%)$, dry dichloromethane $\left(\right.$ dry $\left.\mathrm{CH}_{2} \mathrm{Cl}_{2}\right)$ $(>99.5 \%$; water content, $<0.001 \%)$, dry tetrahydrofuran $(\mathrm{THF})(>99.5 \%$; water content, $<0.001 \%)$, dry acetonitrile $\left(\mathrm{CH}_{3} \mathrm{CN}\right)(>99.5 \%$; water content, $<0.001 \%)$, methanol $(>99.5 \%)$, acetone $(>99.0 \%), n$ hexane $(>95.0 \%)$, ethyl acetate $(>99.5 \%)$, dimethylformamide (DMF) $(>99.5 \%)$, and chloroform $\left(\mathrm{CHCl}_{3}\right)(>99.0 \%)$ were obtained from Kanto Chemical Co., Ltd., and used without further purification.

Measurements. The spectra of ${ }^{1} \mathrm{H}(400 \mathrm{MHz}),{ }^{13} \mathrm{C}$ NMR (100 MHz), distortionless enhancement by polarization transfer (DEPT), and ${ }^{13} \mathrm{C}-{ }^{1} \mathrm{H}$ correlation spectroscopy (COSY) were recorded using a JEOL JNM-A400II instrument. The molecular weight values of polymers $\mathbf{2}, \mathbf{4}$ and $\mathbf{6}$ were determined by size exclusion chromatography (SEC) in $\mathrm{THF}\left(1.0 \mathrm{~mL} \cdot \mathrm{min}^{-1}\right)$ at $40{ }^{\circ} \mathrm{C}$ using an Agilent 1100 series instrumentation equipped with two Shodex KF-804L columns (linear, $8.0 \mathrm{~mm} \times 300 \mathrm{~mm}$; exclusion limit, $4 \times 10^{5}$; bead size, $7 \mu \mathrm{m}$ ), a DAWN 8 multi-angle laser light scattering (MALLS) detector (Wyatt Technology, Santa Barbara, CA), a Viscostar viscosity detector (Wyatt Technology), and an Optilab rEX 


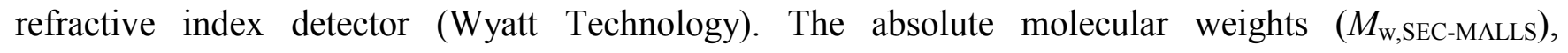
polydispersity $\left(M_{\mathrm{w}, \text { SEC-MALLS }} / M_{\mathrm{n}, \mathrm{SEC}-\mathrm{MALLS}}\right)$, intrinsic viscosity $([\eta])$, refractive index change $\left(\mathrm{d} n \cdot \mathrm{d} c^{-1}\right)$, and Mark-Houwink-Sakurada constants, $\alpha$ and K, were estimated by ASTRA 5.1.6.0 software (Wyatt Technology). The relative molecular weight $\left(M_{\mathrm{w}, \mathrm{SEC}}\right)$ and the polydispersity $\left(M_{\mathrm{w}, \mathrm{SEC}} / M_{\mathrm{n}, \mathrm{SEC}}\right)$ in THF were calculated on the basis of a polystyrene calibration. The molecular weight values of polymer $\mathbf{3}$ were determined by size exclusion chromatography (SEC) in a $0.2 \mathrm{~mol} \cdot \mathrm{L}^{-1} \mathrm{NaNO}_{3}$ aqueous solution $(1.0$ $\mathrm{mL} \cdot \mathrm{min}^{-1}$ ) at $40{ }^{\circ} \mathrm{C}$ using an Agilent 1100 series instrumentation equipped with two Tosoh TSKgel GMPW $_{\mathrm{XL}}$ columns (linear, $7.8 \mathrm{~mm} \times 300 \mathrm{~mm}$; exclusion limit, $5 \times 10^{7}$; bead size, $13 \mu \mathrm{m}$ ), a DAWN 8 multi-angle laser light scattering (MALLS) detector (Wyatt Technology), a Viscostar viscosity detector (Wyatt Technology), and an Optilab rEX refractive index detector (Wyatt Technology). The $M_{\mathrm{w}, \text { SEC- }}$ MALls, $M_{\mathrm{w}, \text { SEC-MAlls }} / M_{\mathrm{n}, \text { SEC-MALls, }}$ [ $\left.\eta\right], \mathrm{d} n \cdot \mathrm{d} c^{-1}$, and Mark-Houwink-Sakurada constants, $\alpha$ and $\mathrm{K}$, were estimated by ASTRA 5.1.6.0 software (Wyatt Technology). Preparative SEC for the chloroform-soluble polymers was performed in chloroform $\left(3.5 \mathrm{~mL} \cdot \mathrm{min}^{-1}\right)$ at $23{ }^{\circ} \mathrm{C}$ using a JAI LC-9201 (Japan Analytical Industry Co., Ltd., Japan) equipped with a JAI JAIGEL-3H column (20 mm x 600 mm; exclusion limit, $7 \times 10^{4}$ ) and a JAI RI-50s refractive index detector. The preparative SEC for the water-soluble polymers was performed in water $\left(14 \mathrm{~mL} \cdot \mathrm{min}^{-1}\right)$ at $23{ }^{\circ} \mathrm{C}$ using a JAI LC-928 (Japan Analytical Industry Co., Ltd., Japan) equipped with a JAI JAIGEL-W253-40 column (40 mm x $500 \mathrm{~mm}$; exclusion limit, $\left.5 \times 10^{4}\right)$ and a JAI RI-50s refractive index detector. The elemental analysis was performed using a MICRO CORDER JM10 and Dionex DX-500 (Instrumental Analysis Division, Management Center, Creative Research Instaction Sousei, Hokkaido University). The measurement of the optical rotations was performed in $\mathrm{CHCl}_{3}$ or $\mathrm{H}_{2} \mathrm{O}$ using a Jasco DIP-1000 digital polarimeter $(\lambda=589 \mathrm{~nm})$. The FI-MASS spectroscopy measurement was performed using a JEOL JMS-SX102A mass spectrometer (GC-MS \& NMR Laboratory, Graduate School of Agriculture, Hokkaido University). The UV-vis spectra were measured at $70{ }^{\circ} \mathrm{C}$ with a 10 -mm path length using a JASCO V-550 spectrometer with a deuterium lamp as the light source for the UV range (190-350 nm) and a halogen lamp for the visible range (330-900 nm). The dynamic light scattering (DLS) measurement of the obtained Au particles was performed at $25{ }^{\circ} \mathrm{C}$ using 
an Otsuka Electronics FDLS-3000 light scattering spectrophotometer equipped with a solid state laser $(\lambda$ $=532 \mathrm{~nm}$, scattering angle $=90^{\circ}$ ). Before the measurement, the samples were filtered using $0.45 \mu \mathrm{m}$ PTFE membrane filters to eliminate any dust particles. The data analysis was carried out using the histogram methods including the Marquadt analysis.

Anionic Polymerization of 1. All the anionic polymerizations of 1 were carried out using a storage flask with a needle valve under an argon atmosphere. A typical polymerization procedure (entry 2 in Table 1) is as follows: $1.0 \mathrm{~mol} \cdot \mathrm{L}^{-1} t$-BuOK in a THF solution $(0.50 \mathrm{~mL}, 0.50 \mathrm{mmol},[1] /[t$-BuOK $]=20)$ was added to a solution of the monomer $1(2.02 \mathrm{~g}, 10.0 \mathrm{mmol})$ in dry THF $\left(4.50 \mathrm{~mL},[\mathbf{1}]=2.0 \mathrm{~mol} \cdot \mathrm{L}^{-1}\right)$ at $50{ }^{\circ} \mathrm{C}$ using a microsyringe. After $600 \mathrm{~h}$, the reaction mixture was poured into a large amount of methanol, then the solution was neutralized with dry ice. After evaporating the solvent, the residue was purified by reprecipitation from methanol-water to yield the crude polymer. The precipitate was redissolved in $\mathrm{CHCl}_{3}(15 \mathrm{~mL})$ and applied to the preparative SEC to remove the unreacted monomer 1. The concentrated polymer solution was dried in vacuo to give a white solid polymer 2 in a $68.4 \%$ yield $(1.38 \mathrm{~g}) ; M_{\mathrm{w}, \mathrm{SEC}}(\mathrm{THF})=1,400 ; M_{\mathrm{w}, \mathrm{SEC}} / M_{\mathrm{n}, \mathrm{SEC}}(\mathrm{THF})=1.28 ; M_{\mathrm{w}, \mathrm{SEC}-\mathrm{MALLS}}(\mathrm{THF})=7,400 ; M_{\mathrm{w}, \mathrm{SEC}-}$ MALLS $/ M_{\mathrm{n}, \mathrm{SEC}-\mathrm{MALLS}}(\mathrm{THF})=1.37 ; \mathrm{d} n \cdot \mathrm{d} c^{-1}(\mathrm{THF})=0.080 \mathrm{~mL} \cdot \mathrm{g}^{-1} ;[\alpha]_{\mathrm{D}}=-23.1^{\circ}\left(c 1.00, \mathrm{CHCl}_{3}, 24{ }^{\circ} \mathrm{C}\right)$. ${ }^{1} \mathrm{H}$ NMR $\left(\mathrm{CD}_{2} \mathrm{Cl}_{2}\right): \delta 5.87$ (br.s, $\mathrm{H}-1$ ), 4.80 -3.20 (m, including peaks at 4.59, 4.48, 4.26, 4.01, 3.73, 3.60, and $3.47 \mathrm{ppm}), 3.06$ (br.s), 2.93-2.70 (m, epoxy group), $1.44\left(\mathrm{~s},=\mathrm{C}\left(\mathrm{CH}_{3}\right)_{2}\right)$ and $1.28 \mathrm{ppm}\left(\mathrm{s},=\mathrm{C}(\mathrm{CH})_{2}\right)$. ${ }^{13} \mathrm{C} \mathrm{NMR}\left(\mathrm{CD}_{2} \mathrm{Cl}_{2}\right): \delta 112.14\left(=C\left(\mathrm{CH}_{3}\right)_{2}\right), 105.74(\mathrm{C}-1), 105.44(\mathrm{C}-1), 85.55,84.20,82.31,80.46,74.65$, 73.45, 68.60, 48.49 (epoxy group), 46.98 (epoxy group), $26.96\left(=\mathrm{C}\left(\mathrm{CH}_{3}\right)_{2}\right)$, and $26.35 \mathrm{ppm}\left(=\mathrm{C}\left(\mathrm{CH}_{3}\right)_{2}\right)$. It is hard to estimate the degree of branching value because the NMR peaks due to each branch structure were broadened and overlapped.

Cationic Polymerization of 1. All procedures were performed using a Schlenk flask under an argon atmosphere. A typical procedure for the cationic polymerization (entry 4 in Table 1) is as follows: $\mathrm{BF}_{3} \cdot \mathrm{OEt}_{2}\left(8.0 \mu \mathrm{L}, 62.5 \mu \mathrm{mol},[\mathbf{1}] /\left[\mathrm{BF}_{3} \cdot \mathrm{OEt}_{2}\right]=40\right)$ was added to a solution of $\mathbf{1}(0.505 \mathrm{~g}, 2.50 \mathrm{mmol})$ in dry $\mathrm{CH}_{2} \mathrm{Cl}_{2}\left(5.0 \mathrm{~mL},[\mathbf{1}]=0.5 \mathrm{~mol} \cdot \mathrm{L}^{-1}\right)$ at $10{ }^{\circ} \mathrm{C}$ using a microsyringe. After $24 \mathrm{~h}$, the polymerization 
was terminated by adding methanol containing a small portion of an aqueous ammonia solution. After evaporating the solvent, the residue was purified by reprecipitation from methanol-water to yield the crude polymer. The precipitate was redissolved in $\mathrm{CHCl}_{3}(4 \mathrm{~mL})$ and applied to the preparative SEC to remove the unreacted monomer $\mathbf{1}$. The concentrated polymer solution was dried in vacuo to give a white solid polymer 2 in a $68.5 \%$ yield $(346 \mathrm{mg}) ; M_{\mathrm{w}, \mathrm{SEC}}(\mathrm{THF})=4,100 ; M_{\mathrm{w}, \mathrm{SEC}} / M_{\mathrm{n}, \mathrm{SEC}}(\mathrm{THF})=1.29 ; M_{\mathrm{w}, \mathrm{SEC}-}$ $\operatorname{MALLS}(\mathrm{THF})=15,000 ; M_{\mathrm{w}, \text { SEC-MALLS }} / M_{\mathrm{n}, \text { SEC-MALlS }}(\mathrm{THF})=1.45 ; \mathrm{d} n \cdot \mathrm{d} c^{-1}(\mathrm{THF})=0.079 \mathrm{~mL} \cdot \mathrm{g}^{-1} ;[\alpha]_{\mathrm{D}}=-$ $50.6^{\circ}\left(c 1.00, \mathrm{CHCl}_{3}, 24{ }^{\circ} \mathrm{C}\right)$. The ${ }^{1} \mathrm{H}$ and ${ }^{13} \mathrm{C}$ NMR spectra of 2 (entry 4 ) are almost similar to those of entry 7.

Cationic Polymerization of 1 using Slow-monomer-addition Strategy. A typical procedure for the cationic polymerization (entry 7 in Table 1 ) using the slow-monomer-addition strategy ${ }^{87}$ is as follows: $\mathrm{BF}_{3} \cdot \mathrm{OEt}_{2}\left(32.0 \mu \mathrm{L}, 250 \mu \mathrm{mol},[1] /\left[\mathrm{BF}_{3} \cdot \mathrm{OEt}_{2}\right]=40\right)$ was added to a solution of $\mathbf{1}(0.404 \mathrm{~g}, 2.00 \mathrm{mmol})$ in dry $\mathrm{CH}_{2} \mathrm{Cl}_{2}\left(4.0 \mathrm{~mL},[1]=0.5 \mathrm{~mol} \cdot \mathrm{L}^{-1}\right)$ at $10{ }^{\circ} \mathrm{C}$ using a microsyringe. $\mathrm{A} \operatorname{dry} \mathrm{CH}_{2} \mathrm{Cl}_{2}(16.0 \mathrm{~mL},[1]=$ $\left.0.5 \mathrm{~mol} \cdot \mathrm{L}^{-1}\right)$ solution of $\mathbf{1}(1.62 \mathrm{~g}, 8.00 \mathrm{mmol})$ in a microsyringe was then slowly added to the mixture at $10{ }^{\circ} \mathrm{C}$ using a dosing pump. The drip rate was $15.0 \mu \mathrm{L} \cdot \mathrm{min}^{-1}$, i.e., the addition time of 1 was $17.8 \mathrm{~h}$. After $24 \mathrm{~h}$, the polymerization was terminated by adding $400 \mathrm{~mL}$ of methanol containing a small portion of an aqueous ammonia solution. After evaporating the solvent, the residue was purified by reprecipitation from methanol-water to yield the crude polymer. The precipitate was redissolved in $\mathrm{CHCl}_{3}(15 \mathrm{~mL})$ and applied to the preparative SEC to remove the unreacted monomer 1 . The concentrated polymer solution was dried in vacuo to give a white solid polymer $\mathbf{2}$ in a $66.1 \%$ yield (1.34 $\mathrm{g}) ; M_{\mathrm{w}, \mathrm{SEC}}(\mathrm{THF})=8,600 ; M_{\mathrm{w}, \mathrm{SEC}} / M_{\mathrm{n}, \mathrm{SEC}}(\mathrm{THF})=1.26 ; M_{\mathrm{w}, \mathrm{SEC}-\mathrm{MALLS}}(\mathrm{THF})=122,400 ; M_{\mathrm{w}, \mathrm{SEC}-}$ $\operatorname{MALls} / M_{\mathrm{n}, \text { SeC-MAlls }}(\mathrm{THF})=1.70 ; \mathrm{d} n \cdot \mathrm{d} c^{-1}(\mathrm{THF})=0.074 \mathrm{~mL} \cdot \mathrm{g}^{-1} ;[\alpha]_{\mathrm{D}}=-22.2^{\circ}\left(c 1.00, \mathrm{CHCl}_{3}, 25^{\circ} \mathrm{C}\right)$. ${ }^{1} \mathrm{H}$ NMR $\left(\mathrm{CD}_{2} \mathrm{Cl}_{2}\right)$ : $\delta 5.87$ (br.s, H-1), $5.20-2.40$ (br, including peaks at 4.47, 4.28, 4.18, 3.99, 2.91(epoxy group), 2.81 (epoxy group), 2.66 and $2.63 \mathrm{ppm}), 1.44\left(\mathrm{~s},=\mathrm{C}\left(\mathrm{CH}_{3}\right)_{2}\right), 1.28 \mathrm{ppm}$ (s, $\left.=\mathrm{C}\left(\mathrm{CH}_{3}\right)_{2}\right)$, and $0.89 \mathrm{ppm} .{ }^{13} \mathrm{C} \mathrm{NMR}\left(\mathrm{CD}_{2} \mathrm{Cl}_{2}\right): \delta 111.95\left(=\mathrm{C}\left(\mathrm{CH}_{3}\right)_{2}\right), 106.83(\mathrm{C}-1), 105.40(\mathrm{C}-1), 101.49$, 86.00-63.00 (m, including peaks at $85.62,84.24,82.16,79.80,75.35,72.03,69.39,68.38), 27.05$ 
$\left(=\mathrm{C}\left(\mathrm{CH}_{3}\right)_{2}\right)$, and $26.42 \mathrm{ppm}\left(=\mathrm{C}\left(\mathrm{CH}_{3}\right)_{2}\right)$. It is hard to estimate the degree of branching value because the NMR peaks due to each branch structure were broadened and overlapped.

Methylation of polymer 2. Silver oxide $(0.50 \mathrm{~g}, 2.20 \mathrm{mmol})$ and methyl iodide $(3.00 \mathrm{~mL}, 48.6 \mathrm{mmol})$ were added to polymer $2(78.2 \mathrm{mg}, 0.39$ unit-mmol, entry 2 in Table 1$)$ in $5 \mathrm{~mL}$ of dry acetonitrile. After the mixture was refluxed for $21 \mathrm{~h}$, the insoluble parts were removed by filtration and the solvent was evaporated. The residue was redissolved in $\mathrm{CHCl}_{3}(1 \mathrm{~mL})$ and applied to the preparative SEC to prepare the resulting polymer. The concentrated polymer solution was dried in vacuo to give a white solid polymer 4 in an $80.1 \%$ yield $(67.0 \mathrm{mg})$; The degree of methylation, which was estimated from the ${ }^{1} \mathrm{H}$ NMR measurement, was ca. $100 \% . M_{\mathrm{w}, \mathrm{SEC}-\mathrm{MALLS}}(\mathrm{THF})=4,200 ; M_{\mathrm{w}, \mathrm{SEC}-\mathrm{MALLS}} / M_{\mathrm{n}, \mathrm{SECMALLS}}(\mathrm{THF})=$ 1.49; $\mathrm{d} n \cdot \mathrm{d} c^{-1}(\mathrm{THF})=0.076 \mathrm{~mL} \cdot \mathrm{g}^{-1} ; \quad[\eta]=4.7 \mathrm{~mL} \cdot \mathrm{g}^{-1} ;$ The Mark-Houwink-Sakurada exponents, $\alpha$ and $\mathrm{K}$, are 0.22 and $0.90 \mathrm{~mL} \cdot \mathrm{g}^{-1}$, respectively. ${ }^{1} \mathrm{H} \mathrm{NMR}\left(\mathrm{CD}_{2} \mathrm{Cl}_{2}\right): \delta 5.83$ (br.s, H-1), 4.55 (br.s), 4.30-3.20 (m, including peaks at 4.11, 3.93, 3.89, 3.77, 3.61, 3.60, $3.48\left(\mathrm{OCH}_{3}\right), 3.46\left(\mathrm{OCH}_{3}\right)$ and $3.44 \mathrm{ppm}$ $\left.\left(\mathrm{OCH}_{3}\right)\right), 3.00-2.70\left(\mathrm{~m}\right.$, including br.s at 2.91, 2.86, and $2.76 \mathrm{ppm}$, epoxy group) $1.45\left(\mathrm{~s},=\mathrm{C}\left(\mathrm{CH}_{3}\right)_{2}\right)$, and $1.29 \operatorname{ppm}\left(\mathrm{s},=\mathrm{C}\left(\mathrm{CH}_{3}\right)_{2}\right) .{ }^{13} \mathrm{C} \mathrm{NMR}\left(\mathrm{CD}_{2} \mathrm{Cl}_{2}\right): \delta 111.60\left(=\mathrm{C}\left(\mathrm{CH}_{3}\right)_{2}\right), 105.06(\mathrm{C}-1), 83.60-80.50(\mathrm{~m}$, including peaks at 83.51, 82.05, and 81.28 ppm), 78.50, 76.90-75.00 (m, including peak at $76.75 \mathrm{ppm})$, 74.00-67.00 (m, including peaks at 72.00, 69.97, and $67.50 \mathrm{ppm}), 59.50-57.00(\mathrm{~m}$, including peaks at 58.43 and 57.64 ppm, $\left.\mathrm{OCH}_{3}\right), 48.15,46.49,29.68,26.77\left(=\mathrm{C}\left(\mathrm{CH}_{3}\right)_{2}\right)$, and $26.28 \mathrm{ppm}\left(=\mathrm{C}\left(\mathrm{CH}_{3}\right)_{2}\right)$.

\section{Synthesis of 5,6-anhydro-1,2- $O$-isopropylidene-3-O-methyl- $\alpha$-D-glucofuranose (5). Silver oxide} (4.60 g, $19.8 \mathrm{mmol})$ and methyl iodide $(1.20 \mathrm{~mL}, 19.8 \mathrm{mmol})$ were added to $\mathbf{1}(1.95 \mathrm{~g}, 9.64 \mathrm{mmol})$ in 5 $\mathrm{mL}$ of dry acetonitrile. After the mixture was refluxed for $20 \mathrm{~h}$, the insoluble parts were removed by filtration and the solvent was evaporated. The residue was purified by column chromatography on silica gel with $n$-hexane/ethyl acetate $\left(2 / 1, \mathrm{v} / \mathrm{v} ; R_{\mathrm{f}}=0.31\right)$ to afford a colorless liquid 5. Yield: $1.92 \mathrm{~g}(92.1 \%)$. ${ }^{1} \mathrm{H}$ NMR $\left(\mathrm{CDCl}_{3}\right): \delta 5.88(\mathrm{~d}, J=3.2 \mathrm{~Hz}, 1 \mathrm{H}, \mathrm{H}-1), 4.58(\mathrm{~m}, 1 \mathrm{H}, \mathrm{H}-2), 3.82(\mathrm{~m}, 1 \mathrm{H}, \mathrm{H}-4), 3.68(\mathrm{~m}, 1 \mathrm{H}$, H-3), (s, 3H, $\left.\mathrm{OCH}_{3}\right), 3.46,3.20(\mathrm{~m}, 1 \mathrm{H}, \mathrm{H}-5), 2.88$ (m, 1H, H-6), $2.74(\mathrm{~m}, 1 \mathrm{H}, \mathrm{H}-6), 1.43$ (s, 3H,

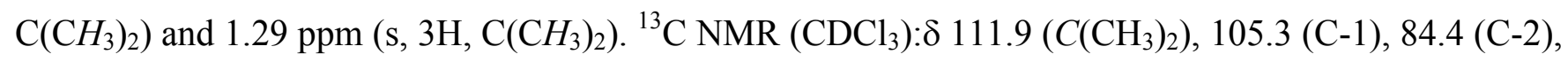


$82.0(\mathrm{C}-3), 81.6(\mathrm{C}-4), 58.4\left(\mathrm{OCH}_{3}\right), 48.1(\mathrm{C}-5), 46.9(\mathrm{C}-6), 26.9\left(\mathrm{C}\left(\mathrm{CH}_{3}\right)_{2}\right)$ and $26.3 \mathrm{ppm}\left(\mathrm{C}(\mathrm{CH})_{2}\right)$.

Anal. Calcd for $\mathrm{C}_{10} \mathrm{H}_{16} \mathrm{O}_{5}$ (216.23): C, 55.55; H, 7.46. Found: C, 55.24; H, 7.31. FI-MS (m/z): $216\left(\mathrm{M}^{+}\right)$.

Anionic Polymerization of 5. The anionic polymerizations of 5 were carried out using a storage flask with a needle valve under an argon atmosphere. $1.0 \mathrm{~mol} \cdot \mathrm{L}^{-1} t$-BuOK in a THF solution $(0.30 \mathrm{~mL}, 0.30$ mmol, $[\mathbf{1}] /[t-\mathrm{BuOK}]=20)$ was added to a solution of $5(1.30 \mathrm{~g}, 6.00 \mathrm{mmol})$ in dry $\mathrm{THF}(2.70 \mathrm{~mL},[\mathbf{1}]=$ $2.0 \mathrm{~mol} \cdot \mathrm{L}^{-1}$ ) at $60{ }^{\circ} \mathrm{C}$ using a microsyringe. After $180 \mathrm{~h}$, the reaction mixture was poured into a large amount of methanol, and the solution was neutralized with dry ice. After evaporating the solvent, the residue was purified by reprecipitation from chloroform- $n$-hexane to yield the crude polymer. The precipitate was redissolved in $\mathrm{CHCl}_{3}(9 \mathrm{~mL})$ and applied to the preparative $\mathrm{SEC}$ to remove the unreacted monomer. The concentrated polymer solution was dried in vacuo to give a white solid polymer, poly(5,6-anhydro-1,2- $O$-isopropylidene-3- $O$-methyl- $\alpha$-D-glucofuranose) (6), in a $65.9 \%$ yield (857 mg); $M_{\mathrm{w}, \mathrm{SEC}-\mathrm{MALLS}}(\mathrm{THF})=11,100 ; M_{\mathrm{w}, \mathrm{SEC}-\mathrm{MALLS}} / M_{\mathrm{n}, \mathrm{SEC}-\mathrm{MALLS}}(\mathrm{THF})=1.26 ; \mathrm{d} n \cdot \mathrm{d} c^{-1}(\mathrm{THF})=0.062 \mathrm{~mL} \cdot \mathrm{g}^{-1} ;$ $[\eta]=6.8 \mathrm{~mL} \cdot \mathrm{g}^{-1}$; Mark-Houwink-Sakurada exponents $\alpha$ and $\mathrm{K}$ are 0.50 and $0.06 \mathrm{~mL} \cdot \mathrm{g}^{-1}$, respectively. $[\alpha]_{\mathrm{D}}=-51.0^{\circ}\left(c 1.00, \mathrm{CHCl}_{3}, 25^{\circ} \mathrm{C}\right) .{ }^{1} \mathrm{H} \mathrm{NMR}\left(\mathrm{CDCl}_{3}\right): \delta 5.93(\mathrm{~d}, J=3.2 \mathrm{~Hz}, \mathrm{H}-1), 5.83,4.54,4.49(\mathrm{~d}$, $J=3.7 \mathrm{~Hz}, \mathrm{H}-2$ ), 4.27 (d, $J=8.7 \mathrm{~Hz}, \mathrm{H}-6), 4.01$ (br.s, H-3 and H-4), 3.87, 3.76 (br.s, H-5), 3.53 (br.s, H6) $3.46\left(\mathrm{~s}, 3 \mathrm{H}, \mathrm{OCH}_{3}\right), 1.45\left(\mathrm{~s}, \mathrm{C}\left(\mathrm{CH}_{3}\right)_{2}\right), 1.27\left(\mathrm{~s}, \mathrm{C}\left(\mathrm{CH}_{3}\right)_{2}\right)$ and $1.17 \mathrm{ppm} .{ }^{13} \mathrm{C} \mathrm{NMR}\left(\mathrm{CDCl}_{3}\right): \delta 111.03$, $110.95\left(\mathrm{C}\left(\mathrm{CH}_{3}\right)_{2}\right), 105.01(\mathrm{C}-1), 82.95(\mathrm{C}-4), 81.76$ (C-2), 79.10 (C-3), 75.65 (C-5), 74.37 (C-6), 72.63 , $57.61\left(\mathrm{OCH}_{3}\right), 27.58,26.76\left(\mathrm{C}\left(\mathrm{CH}_{3}\right)_{2}\right)$ and $26.30\left(\mathrm{C}\left(\mathrm{CH}_{3}\right)_{2}\right)$.

Hydrolysis of polymer 2. Polymer 2 (0.60 g, 2.97 unit-mmol, entry 7) was dissolved in $5 \mathrm{~mL}$ of a 85/15 (v/v) trifluoroacetic acid/water mixture. The solution was magnetically stirred at room temperature for $18 \mathrm{hr}$, and diluted with $40 \mathrm{~mL}$ of water. The solution was neutralized using an aqueous ammonia solution, then dialyzed in water for several days using a Spectra/Por ${ }^{\circledR}$ CE (cellulose Ester) membrane (MWCO: 1000 Dalton, SPECTRUM). After freeze-drying from water, the residue was redissolved in water $(5 \mathrm{~mL})$ and applied to the preparative SEC to purify the resulting polymer. After freeze-drying from water, the hyperbranched 5,6-glucan (3) was isolated as a white powder. The yield was $62.7 \%(335 \mathrm{mg}$, entry 9$) . M_{\mathrm{w}, \mathrm{SEC}-\mathrm{MALLS}}\left(0.2 \mathrm{~mol} \cdot \mathrm{L}^{-1} \mathrm{NaNO}_{3}\right.$ aq. $)=74,400 ; M_{\mathrm{w}, \text { SEC-MALLS }} / M_{\mathrm{n}, \mathrm{SEC}-}$ 
MALLS $\left(0.2 \mathrm{~mol} \cdot \mathrm{L}^{-1} \mathrm{NaNO}_{3}\right.$ aq. $)=2.74 ; \mathrm{d} n \cdot \mathrm{d} c^{-1}\left(0.2 \mathrm{~mol} \cdot \mathrm{L}^{-1} \mathrm{NaNO}_{3}\right.$ aq. $)=0.135 \mathrm{~mL} \cdot \mathrm{g}^{-1} ;[\alpha]_{\mathrm{D}}=+17.3^{\circ}$

(c 1.00, $\mathrm{H}_{2} \mathrm{O}, 25^{\circ} \mathrm{C}$ ). ${ }^{1} \mathrm{H}$ NMR (entry 9, $\mathrm{D}_{2} \mathrm{O}$ including acetone as internal reference): $\delta 6.05$ (br.s), 5.49 (br.s, $\alpha$-franosyl unit, H-1), 5.23 (br.s, $\beta$-franosyl and $\alpha$-pyranosyl units, H-1), and 5.00-3.20 ppm (m, including peaks at 4.64 (br.s, $\beta$ - pyranosyl unit, H-1), 4.28, 4.12, 3.96, 3.71, 3.56, 3.48, 3.26), 1.44, and $1.23 \mathrm{ppm} .{ }^{13} \mathrm{C}$ NMR (entry $9, \mathrm{D}_{2} \mathrm{O}$ including acetone as internal reference): $\delta 102.94$ ( $\beta$-franosyl unit, C1), 97.30 ( $\alpha$-franosyl unit, C-1), 96.58 ( $\beta$ - pyranosyl unit, C-1), 92.74 ( $\alpha$ - pyranosyl unit, C-1), and 88.00-62.00 ppm (m, including signals at 80.92, 77.83, 76.28, 75.48, 74.68, 73.33, 72.04, and 70.45 ppm). For entry 8: $[\alpha]_{\mathrm{D}}+53.6^{\circ}\left(c 1.00, \mathrm{H}_{2} \mathrm{O}, 25{ }^{\circ} \mathrm{C}\right) .{ }^{1} \mathrm{H}$ NMR (entry 8, $\mathrm{D}_{2} \mathrm{O}$ including acetone as internal reference): $\delta 6.01$ (br.s), 5.48 (br.s, $\alpha$-franosyl unit, H-1), 5.22 (br.s, $\beta$-franosyl and $\alpha$-pyranosyl units, H-1), 4.65 (br.s, $\beta$ - pyranosyl unit, H-1) and $4.50-3.20$ ppm (m, including peaks at 4.33, 4.28, 4.12, 4.08, 3.99, 3.60, 3.52, 3.49, 3.47, 3.44, 3.40, 3.34, 3.33, 3.25), 1.52, and 1.36 ppm. ${ }^{13} \mathrm{C}$ NMR (entry 8, $\mathrm{D}_{2} \mathrm{O}$ including acetone as internal reference): $\delta 103.24(\mathrm{C}-1), 102.80$ ( $\beta$-franosyl unit, C-1), 97.31 ( $\alpha$-franosyl unit, C-1), 96.56 ( $\beta$ - pyranosyl unit,C-1), 92.72 ( $\alpha$ - pyranosyl unit, C-1), 85.62, 82.97, 80.89, 80.38, and 79.00-68.00 ppm (m, including signals at 77.65, 76.43, 76.25, 76.05, 75.68, 75.49, $74.62,74.24,74.15,73.27,72.21,72.01,71.68,71.60,71.37,71.03,70.56$, and $69.90 \mathrm{ppm})$.

Formation of Gold Nanoparticle. A typical procedure for the formation of the gold particles is as follows (run 1 in Fig. 15): Polymer 3 (37.5 mg, 0.231 unit-mmol, entry 8) was first dissolved in deionized (Mill-Q) water $(5 \mathrm{~mL})$. The polymer solution (46 unit-mmol $\left.\cdot \mathrm{L}^{-1}, 1.8 \mathrm{~mL}\right)$ was filtered, then kept at $70{ }^{\circ} \mathrm{C}$ for 30 minutes in the UV-cell equipped with a stirring bar. To the polymer solution, the tetrachloroauric acid $\left(\mathrm{HAuCl}_{4}\right)$ aqueous solution $\left(0.01 \mathrm{~mol} \cdot \mathrm{L}^{-1}, 6.67 \mu \mathrm{L}\right)$ was added. The $\mathrm{UV}$-vis spectra of the polymer-metal solution were measured in the wavelength range of 450-600 nm at 1 min intervals with the polymer solution as a reference. The obtained absorbance data were corrected by removing the absorption of the $\mathrm{HAuCl}_{4}$ aqueous solution.

\section{Results and discussion}


Polymerization. The ring-opening polymerizations of 5,6-anhydro-1,2- $O$-isopropylidene- $\alpha-\mathrm{D}-$ glucofuranose (1) were carried out using potassium tert-butoxide ( $t$-BuOK) as the anionic initiator or boron trifluoride diethyletherate $\left(\mathrm{BF}_{3} \cdot \mathrm{OEt}_{2}\right)$ as the cationic initiator. The typical results are summarized in Table 1. When $t$-BuOK was used in dry tetrahydrofuran (THF) as the solvent, the reaction mixtures immediately changed from colorless to dark brown as the reaction progressed, and the polymerization homogeneously proceeded until the end of the polymerization, while the cationic polymerization using $\mathrm{BF}_{3} \cdot \mathrm{OEt}_{2}$ in dry methylene chloride $\left(\mathrm{CH}_{2} \mathrm{Cl}_{2}\right)$ homogeneously proceeded without any color change. The polymers obtained using $t$ - $\mathrm{BuOK}$ or $\mathrm{BF}_{3} \cdot \mathrm{OEt}_{2}$ were a light-yellow solid or a white solid, respectively, which were soluble in chloroform, THF, DMF and methanol, but insoluble in water. The polymer yields for the anionic polymerization (entries 1-3) were in the range of 52.9 to $69.5 \%$ and the increase in conversion was very slow, e.g., $52.9 \%$ at $60{ }^{\circ} \mathrm{C}$ for $160 \mathrm{hr}$ (entry 1 ), $68.4 \%$ at $50{ }^{\circ} \mathrm{C}$ for $600 \mathrm{hr}$ (entry 2 ) and $69.5 \%$ at $50{ }^{\circ} \mathrm{C}$ for $770 \mathrm{hr}$ (entry 3$)$. The weight-average molecular weights $\left(M_{\mathrm{w}, \mathrm{SEC}}\right)$ measured by size exclusion chromatography (SEC) of the resulting polymers ranged from approximately 1,400 to 2,000. In contrast, the polymer yield for the cationic polymerization (entry 4) was $68.5 \%$ for $24 \mathrm{hr}$ and the $M_{\mathrm{w}, \mathrm{SEC}}$ was 4,100 , indicating that the cationic polymerization is much better than the anionic one. ${ }^{88}$

In general, highly branched polymers are known to have spherical conformations in a solution, and the $M_{\mathrm{w}, \mathrm{SEC}}$ of these polymers were often claimed to be too low because the hydrodynamic volumes of these polymers are smaller than the corresponding linear polymers used for the calibration. Therefore, the absolute weight-average molecular weight $\left(M_{\mathrm{w}, \mathrm{SEC}-\mathrm{MALLS}}\right)$ of the resulting polymers was also measured using SEC equipped with a multiangle laser light scattering instrument (MALLS), and was compared with the $M_{\mathrm{w}, \mathrm{SEC}}$ values in Table 1 . The $M_{\mathrm{w}, \mathrm{SEC}-\mathrm{MALLS}}$ values for entries $1-4$ ranged from 7,400 to 15,000 , which were ca. 1.6-5.5 those of the $M_{\mathrm{w}, \mathrm{SEC}}$ values. These results suggest that the resulting polymer has a compact form in solution because of its branched structure.

From the viscosity measurement in THF using SEC equipped with the viscosity detector, the intrinsic viscosities $([\eta])$ of the resulting polymers were observed. The solution viscosities of the polymers obtained using $t$-BuOK were very low in the range from 4.0 to $4.6 \mathrm{~mL} \cdot \mathrm{g}^{-1}$. The $M_{\mathrm{w}, \mathrm{SEC}-\mathrm{MALLS}}$ dependence 
of $[\eta]$ for the polymer (entry 2) is shown in Fig. 2. On the basis of these results, the exponents $(\alpha)$ of the Mark-Houwink-Sakurada equations $\left([\eta]=K M^{\alpha}\right)$ of the polymers obtained using $t$-BuOK were determined to be $0.25-0.27$. In general, $\alpha=0.5$ suggests that the polymer behaves as dense spheres, $\alpha=$ 0.6-0.8 for a flexible chain and $\alpha>1$ for an elongated rod, whereas it is well-known that the $\alpha$ value was less than 0.5 for the various hyperbranched polymers. Our experimental $\alpha$ values were noticeably low, which are ascribed to the compact spherical structure in solution. Therefore, the SEC, MALLS, and viscosity measurement results suggested that the polymer obtained using $t$-BuOK was a branched spherical molecule, i.e., a hyperbranched poly(5,6-anhydro-1,2- $O$-isopropylidene- $\alpha$-D-glucofuranose) (2).

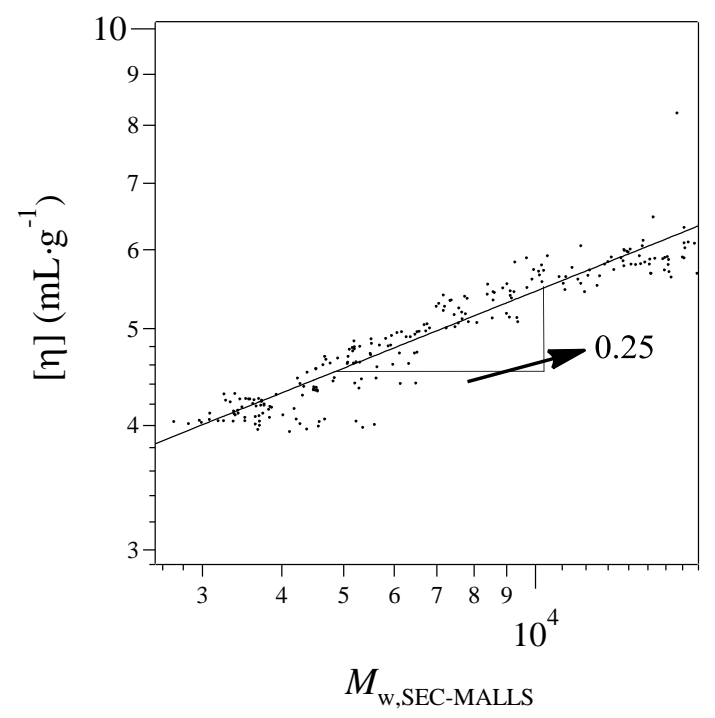

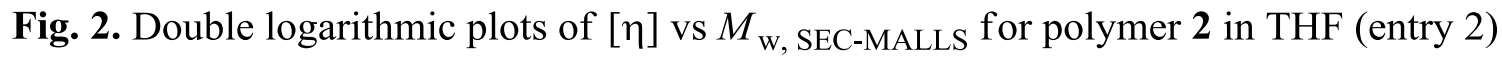

The solution viscosity of the polymer (entry 4) obtained using $\mathrm{BF}_{3} \cdot \mathrm{OEt}_{2}$ was $3.4 \mathrm{~mL} \cdot \mathrm{g}^{-1}$, which was lower than those of the polymers obtained using $t$-BuOK, regardless of the higher molecular weight polymer. In addition, the $\alpha$ value was 0.11 , which was less than those of the polymers obtained using $t$ $\mathrm{BuOK}$. These results indicate that the polymer obtained using $\mathrm{BF}_{3} \cdot \mathrm{OEt}_{2}$ should have a more compact 
spherical structure in solution than the polymer obtained using $t$-BuOK, i.e., the polymer obtained using $\mathrm{BF}_{3} \cdot \mathrm{OEt}_{2}$ should have a higher degree of branching value than the polymer obtained using $t$ - $\mathrm{BuOK}$.

As the efficient preparation method of hyperbranched polymer with both a high molecular weight and a high branching value degree, the slow-monomer-addition strategy ${ }^{87}$ was used for the cationic polymerization of 1 . According to the established time of monomer addition, $16 \mathrm{~mL}$ of the $0.5 \mathrm{~mol} \cdot \mathrm{L}^{-1}$ monomer solution was slowly added to the mixture of $4 \mathrm{~mL}$ of monomer solution and $\mathrm{BF}_{3} \cdot \mathrm{OEt}_{2}$ at $10{ }^{\circ} \mathrm{C}$ using a dosing pump. These results are summarized as entries 5-7 in Table 1 . The slow-monomeraddition strategy results in a very low monomer concentration actually present in the reaction mixture. Thus, the exclusive reaction of the monomer with the growing polyfunctional macromolecules occurs, resulting in a high molecular weight and a high degree of branching. Based on a longer addition time,

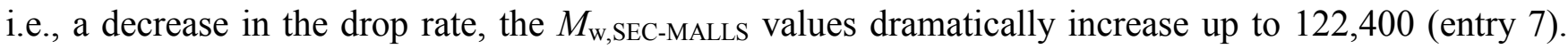
Interestingly, regardless of the higher molecular weight polymer, the $[\eta]$ values were in the range from 3.3 to $3.8 \mathrm{~mL} \cdot \mathrm{g}^{-1}$, which was similar to the value for entry 4 . The $\alpha$ values of the Mark-HouwinkSakurada equations were determined to be very low in range of 0.08 to 0.09 , suggesting that the resulting polymers have a highly branched spherical structure. In addition, the polydispersities $\left(M_{\mathrm{w}, \mathrm{SEC}} / M_{\mathrm{n}, \mathrm{SEC}}\right)$ were found to be in the relatively narrow range of 1.26-1.33. These results indicate that the slow-monomer-addition strategy is a facile method for preparing the hyperbranched polymer 2 with a controlled molecular weight and highly branched structure.

Polymer Structure. In order to investigate the polymer structure, the ${ }^{1} \mathrm{H}$ and ${ }^{13} \mathrm{C}$ NMR measurements were carried out in $\mathrm{CD}_{2} \mathrm{Cl}_{2}$. Parts a and b of Fig. 3 show the ${ }^{1} \mathrm{H}$ NMR spectra of the polymers obtained using $t$-BuOK (entry 2) and $\mathrm{BF}_{3} \cdot \mathrm{OEt}_{2}$ (entry 7), respectively. Though the unreacted monomer was removed using the preparative SEC, in both spectra, the peaks due to the epoxy groups slightly exist in the range of 2.6-3.0 ppm as the starting polymer end, which is a characteristic of a hyperbranched polymer. From a comparison of both spectra, the spectrum of the polymer obtained using $t$-BuOK is obviously different from that of the polymer using $\mathrm{BF}_{3} \cdot \mathrm{OEt}_{2}$, recognizing that the structure of the former is more regular than that of the latter because of distinct splitting of the peaks and narrow peak width for 
the anionically obtained polymer. This trend is also recognized by the comparison of the ${ }^{13} \mathrm{C}$ NMR spectra in Fig. 4. Ring-opening of the monosubstituted epoxide occurs in two ways, i.e., by $\alpha$ - or $\beta$ scission. In general, the polymerization using an anionic catalyst predominantly cleaves the $\mathrm{CH}_{2}-\mathrm{O}$ bond ( $\beta$-scission) via an $\mathrm{SN}_{2}$ displacement to form the regular head-to-tail linkage. Therefore, the difference in the spectra is mainly caused by the stereoregularity of the C-5 carbon in the polymer. Though the anionically obtained polymer has higher stereoregularity, the ${ }^{13} \mathrm{C}$ NMR spectrum contains many peaks due to the C-6 methylene carbons, as shown in Fig. 4c, indicating that the polymer obviously contains some branched structures as irregular structure.

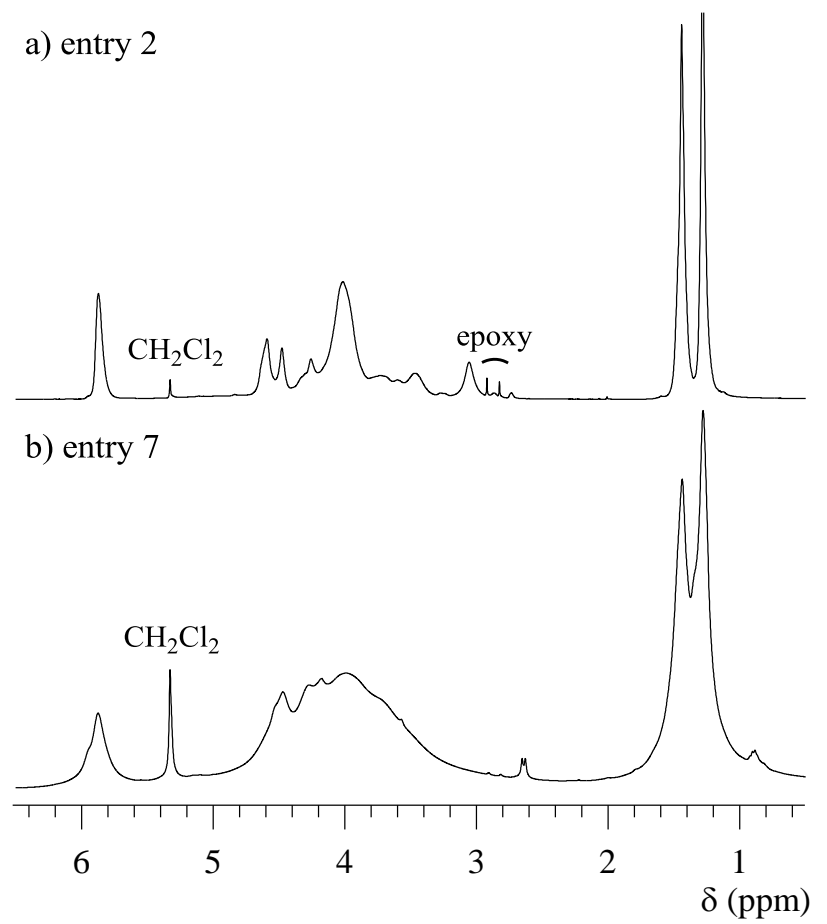

Fig. 3. ${ }^{1} \mathrm{H}$ NMR spectra of polymer 2 in $\mathrm{CD}_{2} \mathrm{Cl}_{2}$ (TMS as internal standard). a) entry 2 and b) entry 7 . 


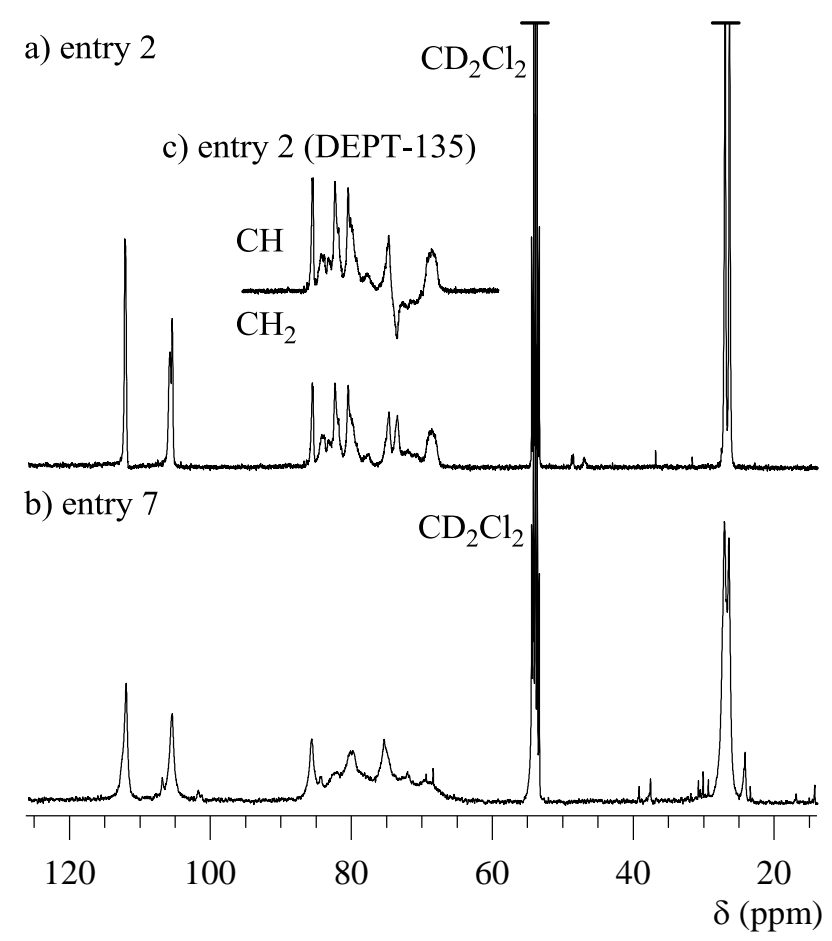

Fig. 4. ${ }^{13} \mathrm{C}$ NMR spectra of polymer 2 in $\mathrm{CD}_{2} \mathrm{Cl}_{2}$ (TMS as internal standard). a) entry 2 and b) entry 7, and DEPT-135 spectrum of entry 2.

In order to investigate the branching structure in polymer 2 , the ${ }^{1} \mathrm{H}$ and ${ }^{13} \mathrm{C} \mathrm{NMR}$ spectra of the methylated hyperbranched polymer (4) were compared with those of the linear analog, poly $(5,6-$ anhydro-1,2-O-isopropylidene-3-O-methyl- $\alpha$-D-glucofuranose) (6). The polymer 4 was prepared by the methylation of the anionically obtained polymer 2 (entry 2) using $\mathrm{CH}_{3} \mathrm{I}$ and $\mathrm{Ag}_{2} \mathrm{O}$ in dry $\mathrm{CH}_{3} \mathrm{CN}_{\text {, as }}$ shown in Fig. 5. On the other hand, the linear polymer 6 was obtained by the anionic polymerization of 5,6-anhydro-1,2-O-isopropylidene-3-O-methyl- $\alpha$-D-glucofuranose (5) using $t$-BuOK, as shown in Fig 6. Parts a and b of Fig. 7 show the ${ }^{1} \mathrm{H}$ NMR spectra of $\mathbf{4}$ and $\mathbf{6}$, respectively. The ${ }^{1} \mathrm{H}$ NMR spectrum of 4 consists of some broad peaks, which is obviously different from that of $\mathbf{6}$. In particular, the methoxy peaks of 4 were split three or more, indicating that there are some methoxy groups in different surroundings, as shown in Fig. S1 (see Supplementary Information). A comparison of the ${ }^{13} \mathrm{C}$ NMR spectra in Fig. S2 (see Supplementary Information) also shows the obvious difference. The ${ }^{13} \mathrm{C}$ NMR 
spectrum of 6 mainly consists of 10 sharp peaks corresponding to the repeating unit, while the spectrum of 4 includes some broad peaks which are due to the irregular structure. In addition, the Mark-HouwinkSakurada exponent $\alpha$ of 4 was 0.22 , whereas the $\alpha$ value of 6 was 0.50 . The NMR and viscosity results strongly support the fact that polymer 4 obviously had some branched structure as an irregular structure, i.e., the polymerization of 1 proceeded through the ring-opening multibranching mechanism to produce the hyperbranched poly(5,6-anhydro-1,2-O-isopropylidene- $\alpha$-D-glucofuranose) 2.

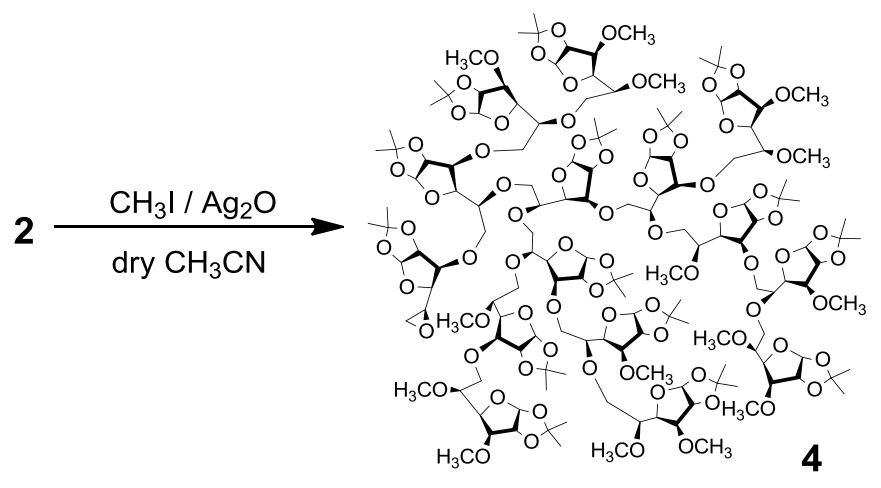

Fig. 5. Methylation of polymer 2.

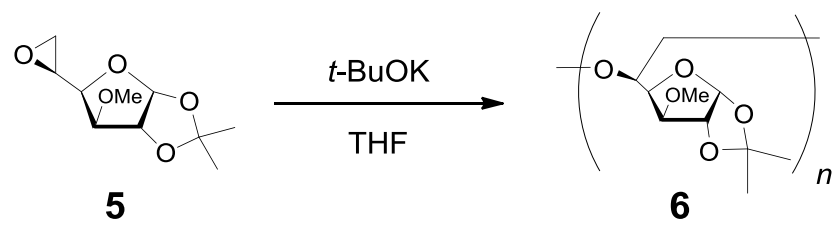

Fig. 6. Anionic polymerization of 5,6-anhydro-1,2- $O$-isopropylidene-3$O$-methyl- $\alpha$-D-glucofuranose (5). 


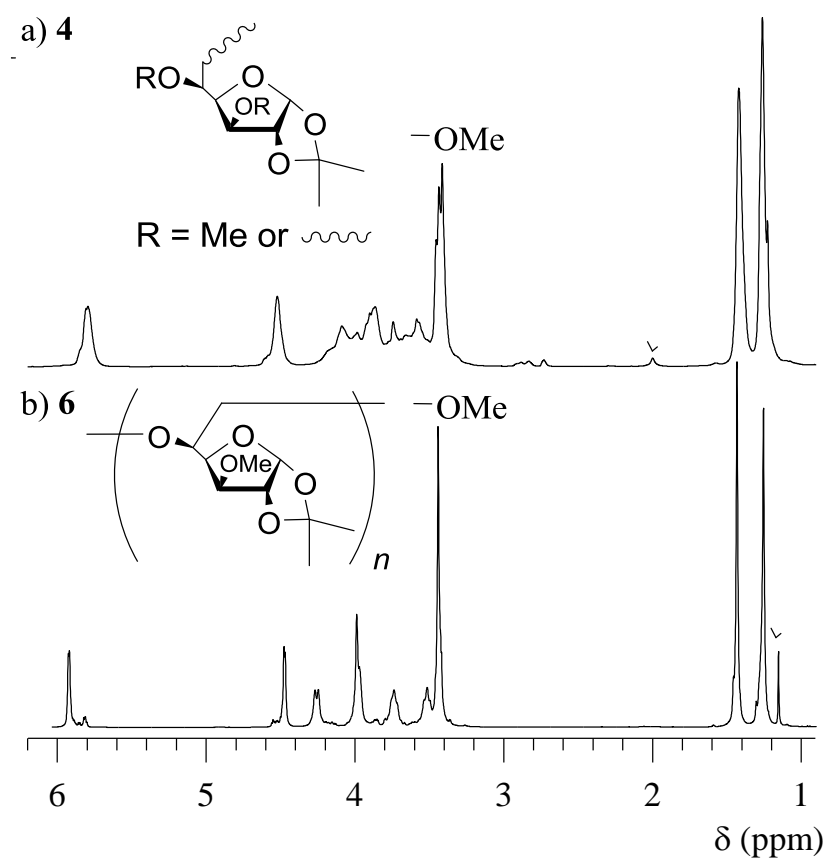

Fig. 7. ${ }^{1} \mathrm{H}$ NMR spectra of a) polymer 4 and b) polymer 6 in $\mathrm{CDCl}_{3}$ (TMS as internal standard).

Polymerization mechanism. Fig. 8 and 9 represent the proposed anionic and cationic polymerization mechanisms, respectively. During the anionic polymerization, the ring-opening occurred through only $\beta$ scission to afford the linear unit with the regular head-to-tail linkage. The branches of the polymers should be produced by the proton transfer from the hydroxy group at C-3 to the other alkoxide and the following ring opening of 1 by the alkoxide at C-3. On the other hand, for the cationic polymerization, the protonated 1 reacted with the epoxy group of a second monomer, and two kinds of linkages through the $\alpha$ - or $\beta$-scission were formed as a linear structure. The branched structure should be produced by proton transfer from the hydroxyl groups in the polymer chains to the oxygen atom of the epoxy group. These reactions mentioned above simultaneously occurred in the polymerization systems and consequently produced the hyperbranched polymer 2 . 


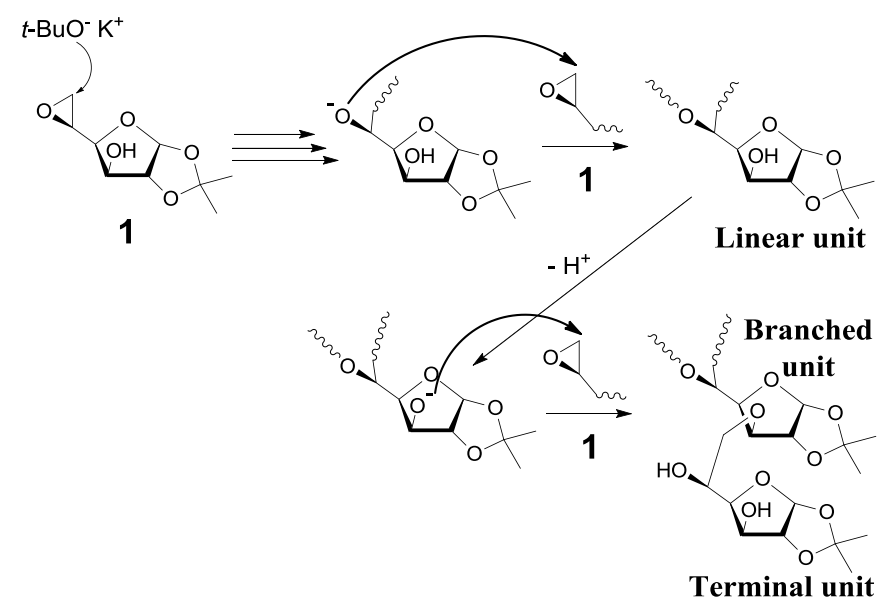

Fig. 8. Proposed mechanism for the anionic polymerization of $\mathbf{1}$.

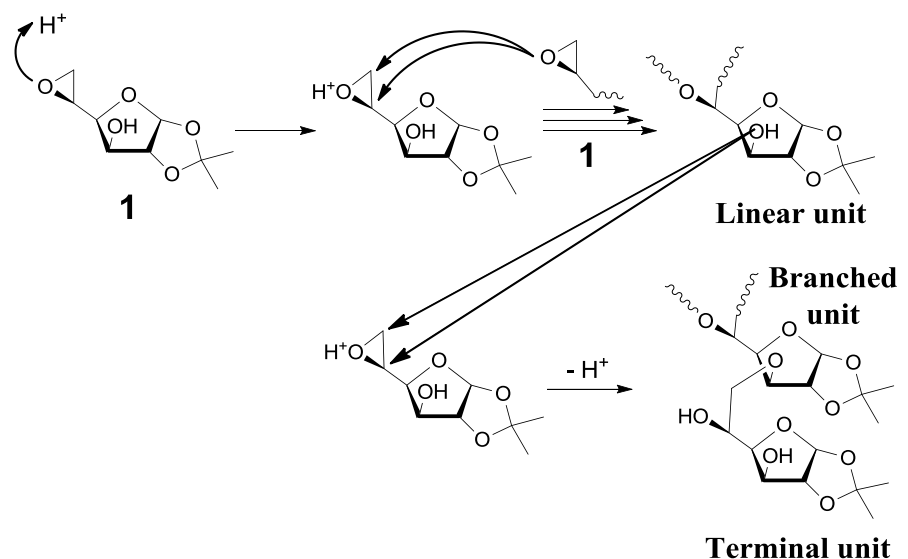

Fig. 9. Proposed mechanism for the cationic polymerization of $\mathbf{1}$.

Hydrolysis of 2. The hydrolysis of polymer 2 was carried out using a mixture of trifluoroacetic acid and water $(85 / 15, \mathrm{v} / \mathrm{v})$ to produce the hyperbranched poly(5,6-anhydro- $\alpha$-D-glucofuranose) (3), e.g., the hyperbranched 5,6-glucan. The obtained polymers 3 were white powders which were soluble in water, and insoluble in chloroform, THF, DMF and methanol, which remarkably differed from the solubility of 2. Fig 10 and 11 show the ${ }^{1} \mathrm{H}$ and ${ }^{13} \mathrm{C}$ NMR spectra of $\mathbf{3}$ (entries 8 and 9) obtained from 2 (entries 2 and 7), respectively. Based on these spectra, it is concluded that the isopropylidene groups were mostly hydrolyzed. 


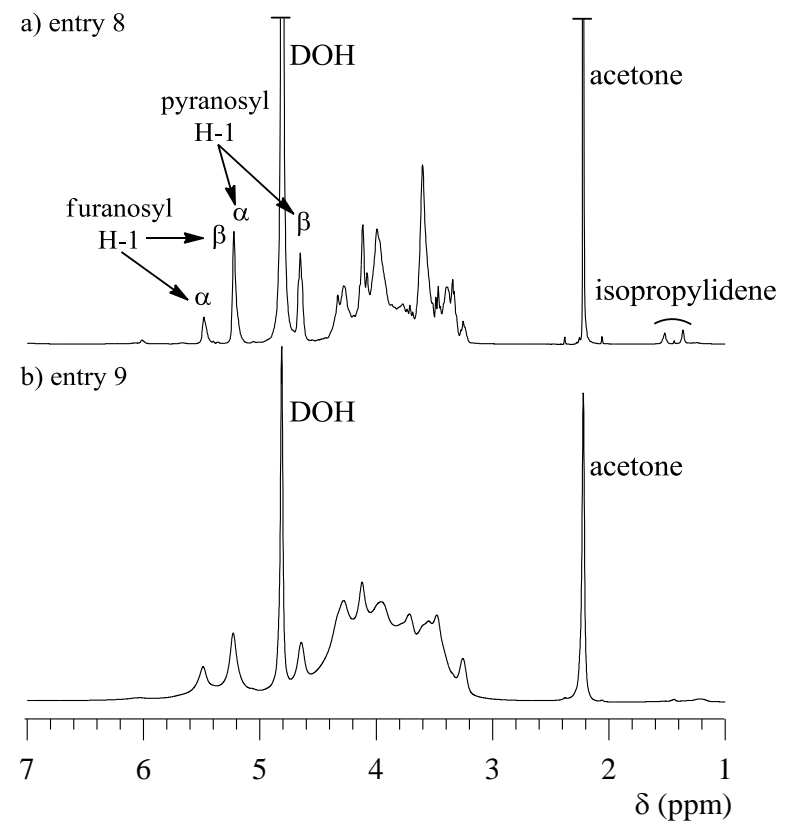

Fig. 10. ${ }^{1} \mathrm{H}$ NMR spectra of polymer 3 in $\mathrm{D}_{2} \mathrm{O}$ (acetone as internal standard). a) entry 8 and b) entry 9 .

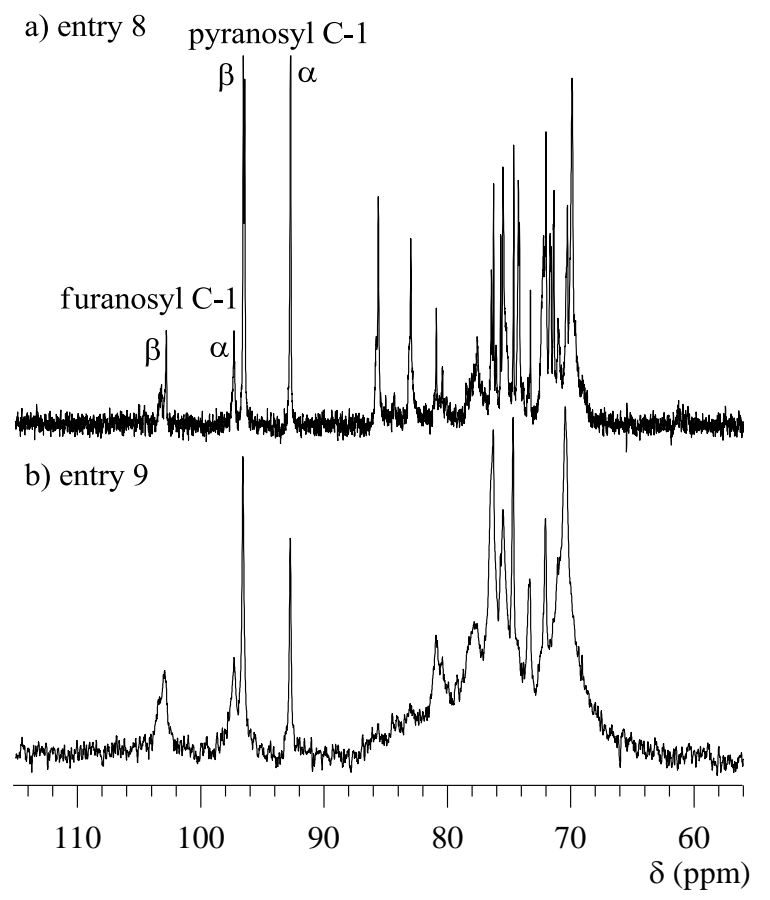

Fig. 11. ${ }^{13} \mathrm{C}$ NMR spectra of polymer 3 in $\mathrm{D}_{2} \mathrm{O}$ (acetone as internal standard). a) entry 8 and b) entry 9 . 


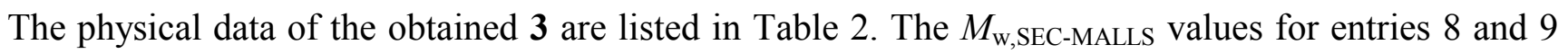
are 3,740 to 74,400 , respectively, which were lower than the calculated $M_{\mathrm{w}}$ values. This indicates that some linkage may break under the hydrolysis conditions. However, the exponents $\alpha$ of the MarkHouwink-Sakurada equations were determined to be 0.36 for entry 8 and 0.26 for entry 9 , as shown in Fig. 12, indicating that the obtained polymer still have the branched structure.
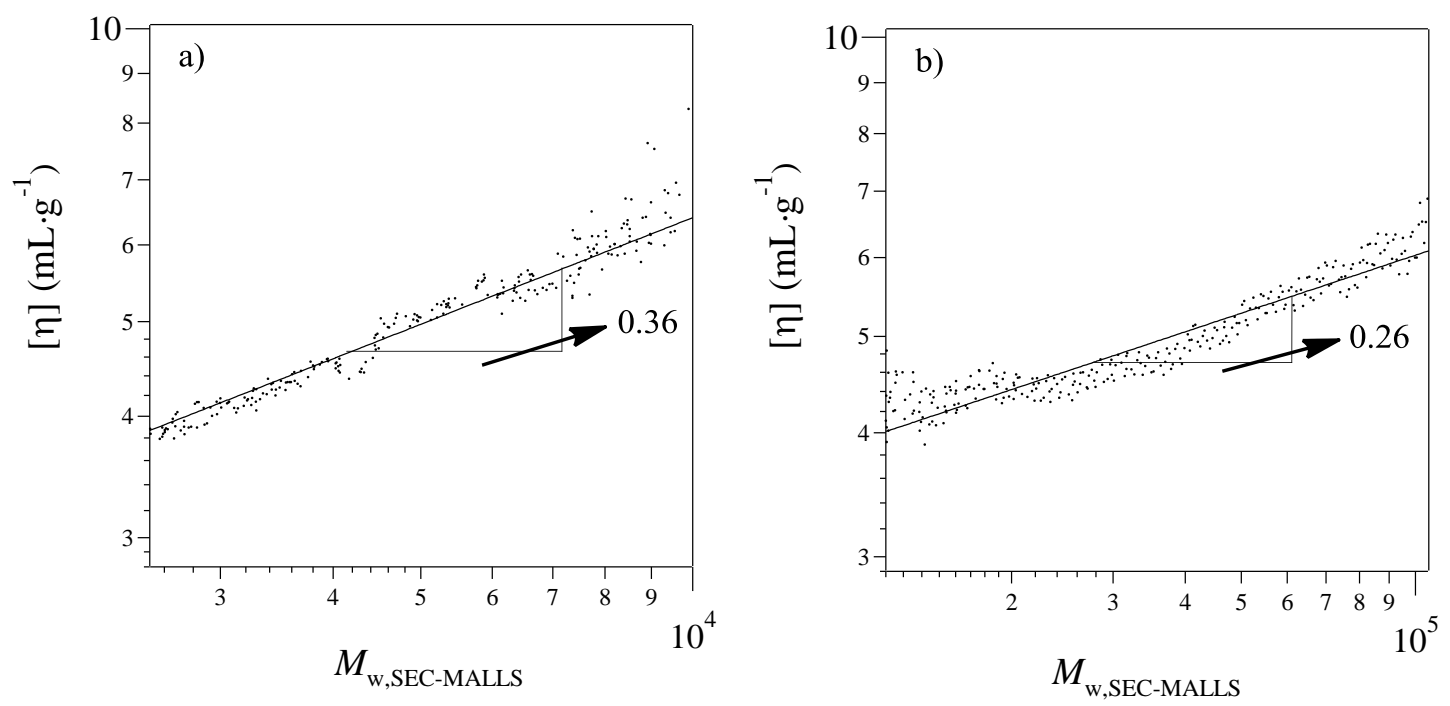

Fig. 12. Double logarithmic plots of [ $\eta$ vs $M_{\mathrm{w}, \text { SEC-MALLS }}$ for polymer 3 in $0.2 \mathrm{~mol} \mathrm{~L}^{-1} \mathrm{NaNO}_{3}$ aqueous solution. a) entry 7 and b) entry 8 .

The ${ }^{1} \mathrm{H}$ and ${ }^{13} \mathrm{C}$ NMR spectra of $\mathbf{3}$ consisted of very complicated peaks, which were constructed by the difference sequences of the D-glucose units. In the ${ }^{13} \mathrm{C}$ NMR spectra, four distinct signals exist in the C1 region. The big signals at 92.74 and 96.58 ppm in Fig 11a, which are very similar to the chemical shifts of the carbons for $\alpha$ - and $\beta$-D-glucopyranoses, ${ }^{89}$ should be assigned to the carbons of the $\alpha$ - and $\beta$ D-glucopyranose units in 3, respectively. In addition, the small signals at 97.30 and 102.94 ppm should be assigned to the carbons of the $\alpha$ - and $\beta$-D-glucofranose units in $\mathbf{3}$, respectively, since these signals are very similar to the chemical shifts of 3,5,6-tri- $O$-methyl $\alpha$ - and $\beta$-D-glucofranoses. ${ }^{90}$ This result 
indicates that after hydrolysis, most of the D-glucofranose units in $\mathbf{2}$ changes to the D-glucopyranose unit in 3. As shown in Fig 13, the D-glucofranose units with a hydroxyl group at C-5 could isomerize to the D-glucopyranose units, e.g., the 6-linked terminal and 3,6-linked linear D-glucofranose units isomerize to the corresponding D-glucopyranose units, while the 5,6-linked linear and 3,5,6-linked dendritic units do not change. Since the intensities of the D-glucopyranose units in Fig 11 are stronger than those of Dglucofranose, polymer 3 includes numerous 6-linked terminal and 3,6-linked linear D-glucopyranose units, which is a characteristic of a hyperbranched polymer.

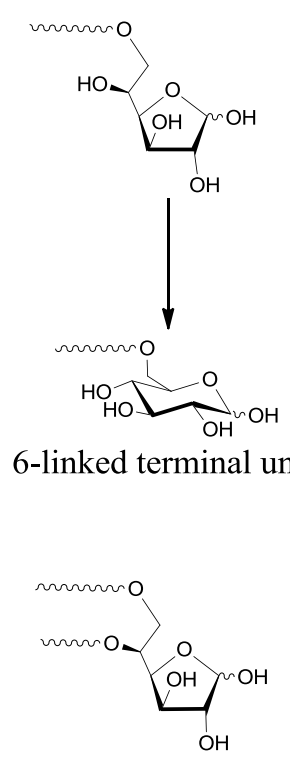

5,6-linked linear unit

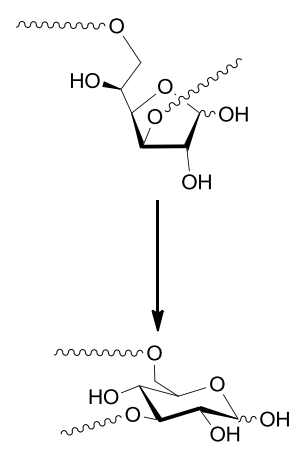

3,6-linked linear unit

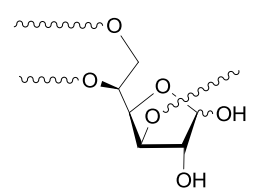

3,5,6-linked dendritic unit

Fig 13. Possible isomerizations of polymer 3 to produce the D-glucopyranose units.

Formation of gold nanoparticle using 3. As mentioned in the previous section, polymer 3 is a novel hyperbranched glycopolymer arranged with numerous reducing D-glucose units on the peripheries of the hyperbranched polymer, whereas almost all of the glycodendrimers, star-shaped glycopolymers, and hyperbranched glycopolymers consist only of nonreducing sugar ends. Therefore, polymer $\mathbf{3}$ is a particularly interesting material, which should be called a "reducing sugar ball". Polymer $\mathbf{3}$ probably has a higher reducing ability than D-glucose because of the glyco-cluster effect or the multivalent effect of 
the reducing D-glucose units. Such a hyperbranched glycopolymer with numerous reducing sugar units is also of considerable interest in a wide variety of fields such as biochemical and medicinal applications.

To estimate the reducing ability of $\mathbf{3}$, the formation of gold particles, which is derived from the reduction of $\mathrm{HAuCl}_{4}$, is demonstrated in the aqueous solution of 3. Fig 14 shows the UV-vis spectra after 150-min mixing of 3 and $\mathrm{HAuCl}_{4}$ aqueous solutions at $70{ }^{\circ} \mathrm{C}$ (runs 1-3). As a comparative experiment, the $\mathrm{UV}$-vis spectrum of the mixture of D-glucose and $\mathrm{HAuCl}_{4}$ aqueous solutions (run 4) is also shown in Fig 14. ${ }^{91}$ After mixing of the $\mathbf{3}$ and $\mathrm{HAuCl}_{4}$ aqueous solutions, the color of the system changed from colorless to light red with time, as shown in Fig. S3 (see Supplementary Information). The UV-vis spectra of the $3-\mathrm{HAuCl}_{4}$ system have a $\lambda_{\max }$ that ranged from $512 \mathrm{~nm}$ to $514 \mathrm{~nm}$, which due to the formation of the gold particles. From previous studies, ${ }^{92}$ the average gold particle diameter can be estimated from the $\lambda_{\max }$, i.e., gold particles of ca. 8 - $12 \mathrm{~nm}$ were obtained by the mixing of $\mathbf{3}$ and the $\mathrm{HAuCl}_{4}$ aqueous solutions. Thus, the average hydrodynamic diameter of the resulting Au particles (run 2 in Fig. 14), which was measured by a dynamic light scattering (DLS) technique, was ca. $11.3 \mathrm{~nm}$, as shown in Fig. S4 (see Supplementary Information).

To obtain the relationship between the formation of the gold particles and the reaction time, the increasing trend in the $\mathrm{UV}$-vis absorbance at $\lambda_{\max }$ is presented in Fig. 15. For all the 3-HAuCl systems $^{-\mathrm{H}}$ (runs 1-3), the UV-vis absorbance sharply increases without an induction time and finally became a constant value within 10 min. $^{93,94}$ On the other hand, the D-glucose- $\mathrm{HAuCl}_{4}$ system (run 4) shows a long induction time, then the absorbance sharply increases as an autocatalytic system. A similar autocatalytic tendency with a long induction time was also reported using the sugar-persubstituted poly(amidoamine) dendrimer, i.e., a sugar ball with numerous nonreducing sugar units. ${ }^{95}$ The results indicate that $\mathbf{3}$ has a high reducing ability that originated from the high density of the reducing sugars in $\mathbf{3}$, i.e., a glycocluster effect or multivalent effect of the reducing sugars. Thus, the reaction rates within 10 min for the 3-HAuCl${ }_{4}$ systems were much faster than that for the D-glucose- $\mathrm{HAuCl}_{4}$ system, as shown in Fig $15 \mathrm{~b}$. This indicates that "reducing sugar ball" 3 effectively act as a sugar based reductant. 


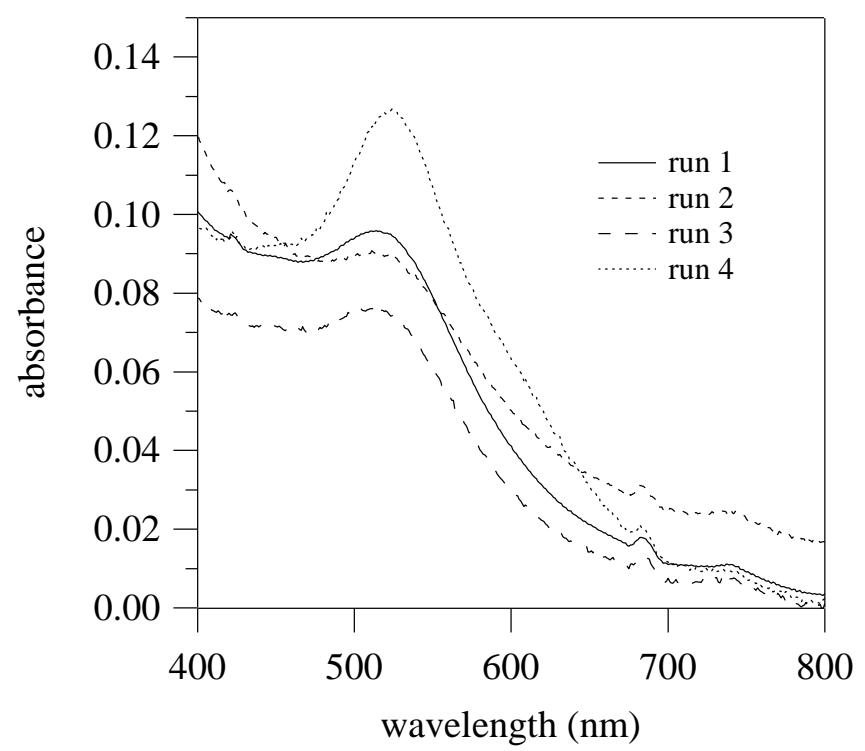

Fig. 14. UV-vis spectra after 150 min mixing of polymer 3 (or D-glucose) and $\mathrm{HAuCl}_{4}$ at 70 ${ }^{\circ} \mathrm{C}$. Run 1; polymer 3 (46 unit-mmol L ${ }^{-1}$ of entry $8,1.8 \mathrm{~mL}$ ) and $\mathrm{HAuCl}_{4}\left(0.01 \mathrm{~mol} \mathrm{~L}^{-1}, 6.67\right.$ $\mu \mathrm{L})$ aqueous solutions, run 2; polymer $3\left(25\right.$ unit-mmol $\mathrm{L}^{-1}$ of entry $\left.8,1.8 \mathrm{~mL}\right)$ and $\mathrm{HAuCl}_{4}$ $\left(0.01 \mathrm{~mol} \mathrm{~L}^{-1}, 6.67 \mu \mathrm{L}\right)$ aqueous solutions, run 3 ; polymer 3 (46 unit-mmol L $\mathrm{m}^{-1}$ of entry $9,1.8$ $\mathrm{mL})$ and $\mathrm{HAuCl}_{4}\left(0.01 \mathrm{~mol} \mathrm{~L}^{-1}, 6.67 \mu \mathrm{L}\right)$ aqueous solutions, and run 4; D-glucose (46 unitmmol L $\left.{ }^{-1}, 1.8 \mathrm{~mL}\right)$ and $\mathrm{HAuCl}_{4}\left(0.01 \mathrm{~mol} \mathrm{~L}^{-1}, 6.67 \mu \mathrm{L}\right)$ aqueous solutions. The maximal wavelengths $\left(\lambda_{\max }\right)$ are $512 \mathrm{~nm}$ for run 1, $514 \mathrm{~nm}$ for run 2, $514 \mathrm{~nm}$ for run 3 and $526 \mathrm{~nm}$ for run 4. 

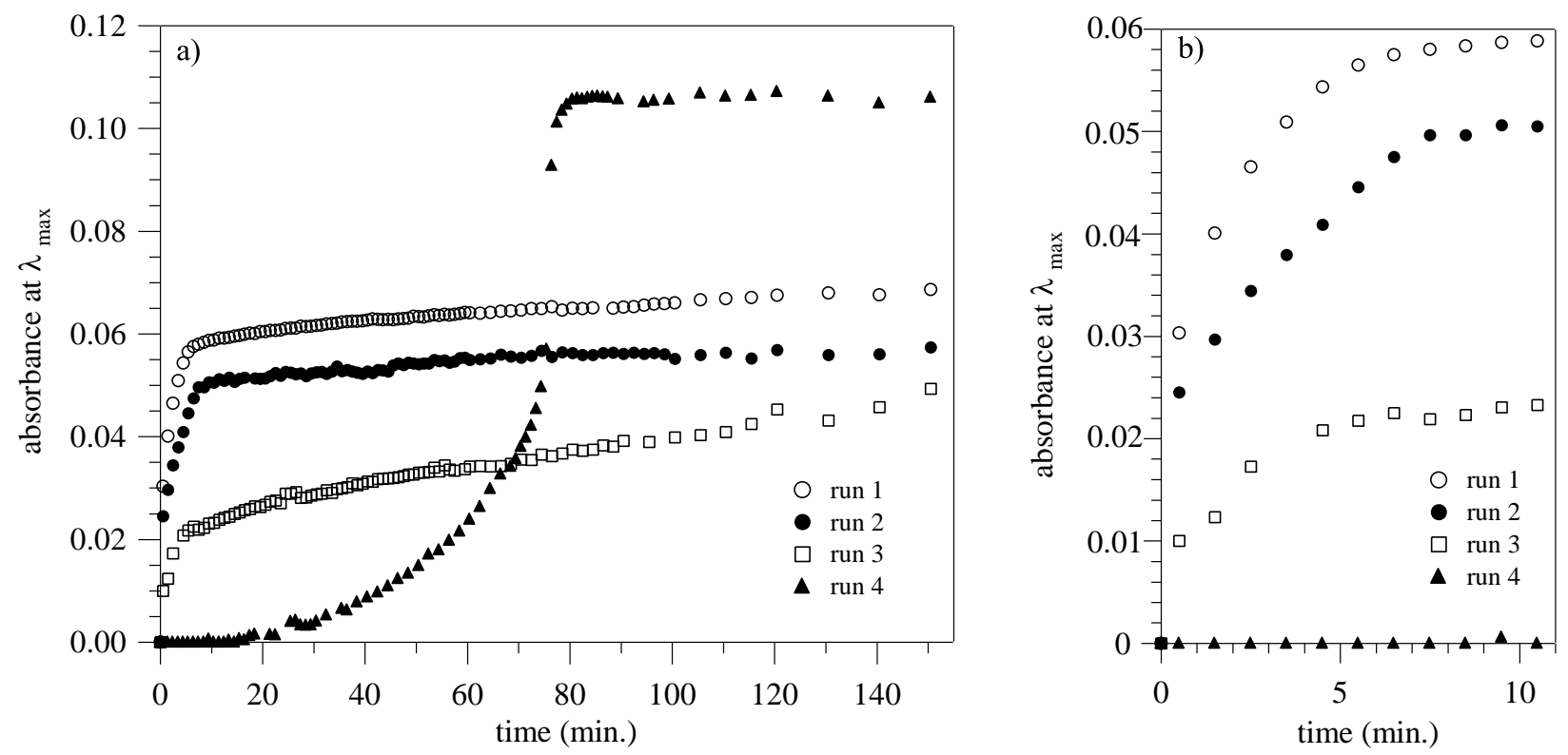

Fig. 15. Change in the UV absorption at $\lambda_{\max }$ of mixtures of polymer 3 (or D-glucose) and $\mathrm{HAuCl}_{4}$ as a function of reaction time at $70{ }^{\circ} \mathrm{C}$. Run 1 (open circle); polymer 3 (46 unit-mmol L-1 of entry $8,1.8 \mathrm{~mL})$ and $\mathrm{HAuCl}_{4}\left(0.01 \mathrm{~mol} \mathrm{~L}^{-1}, 6.67 \mu \mathrm{L}\right)$ aqueous solutions at $512 \mathrm{~nm}$, run 2 (closed circle); polymer 3 (25 unit-mmol L ${ }^{-1}$ of entry $\left.8,1.8 \mathrm{~mL}\right)$ and $\mathrm{HAuCl}_{4}\left(0.01 \mathrm{~mol} \mathrm{~L}^{-1}, 6.67\right.$ $\mu \mathrm{L}$ ) aqueous solutions $514 \mathrm{~nm}$, run 3 (open square); polymer 3 (46 unit-mmol L ${ }^{-1}$ of entry 9, 1.8 $\mathrm{mL})$ and $\mathrm{HAuCl}_{4}\left(0.01 \mathrm{~mol} \mathrm{~L}^{-1}, 6.67 \mu \mathrm{L}\right)$ aqueous solutions $514 \mathrm{~nm}$, and run 4 (closed triangle); D-glucose (46 unit-mmol L $\left.{ }^{-1}, 1.8 \mathrm{~mL}\right)$ and $\mathrm{HAuCl}_{4}\left(0.01 \mathrm{~mol} \mathrm{~L}^{-1}, 6.67 \mu \mathrm{L}\right)$ aqueous solutions 526 $\mathrm{nm}$. a) Overall figure and b) the expanded figure in the range of 0 to $10 \mathrm{~min}$. The obtained absorbance data were corrected by removing the absorption of the $\mathrm{HAuCl}_{4}$ aqueous solution.

Conclusions. In this study, we performed the anionic or cationic ring-opening multibranching polymerization of 5,6-anhydro-1,2-O-isopropylidene- $\alpha$-D-glucofuranose (1) as a latent cyclic $\mathrm{AB}_{2}$-type monomer. The polymerizations proceeded through the proton-transfer reaction mechanism to produce hyperbranched poly(5,6-anhydro-1,2-O-isopropylidene- $\alpha$-D-glucofuranose) (2). In particular, the cationic polymerization with the slow-monomer-addition strategy is a facile method leading to the polymers with a high molecular weight and highly-branched structure. The weight-average molecular weight ( $\left.M_{\mathrm{w}, \mathrm{SEC}-\mathrm{MALLS}}\right)$ values of 2 measured by multi-angle laser light scattering (MALLS) varied in the range of 7,400 to 122,400 , which were significantly higher than the weight-average molecular weight $\left(M_{\mathrm{w}, \mathrm{SEC}}\right)$ values by size exclusion chromatography (SEC). The intrinsic viscosities ([ๆ]) of these 
polymers were very low in the range of 3.3-4.6 $\mathrm{mL} \cdot \mathrm{g}^{-1}$ and the Mark-Houwink-Sakurada exponent $\alpha$ was calculated to be $0.08-0.28$. These results of the MALLS, SEC, and viscosity measurements suggested that these polymers exist in a compact spherical conformation in solution because of their highly-branched structure. A water-soluble hyperbranched 5,6-glucan (3) was also synthesized by the hydrolysis of polymer 2. Polymer $\mathbf{3}$ is a novel hyperbranched glycopolymer arranged with numerous reducing D-glucose units on the peripheries of the polymer, and has a high reducing ability derived from the glycol-cluster effect or the multivalent effect of the reducing D-glucose units, i.e., the "reducing sugar ball" 3 effectively acts as a sugar-based reductant. Such a hyperbranched glycopolymer with numerous reducing sugar units can be expected to be useful in a wide variety of fields such as biochemical and medicinal applications; for example, a biocompatible reductant, antioxidant, and a part of the carrier for a drug delivery system, etc.

Acknowledgements. This study was supported by the Industrial Technology Research Grant Program in 2005 from the New Energy and Industrial Technology Development Organization (NEDO) of Japan and the Research Fellowships of the Japan Society for the Promotion of Science (JSPS) for Young Scientists. The authors thank the OPEN FACILITY (Hokkaido University Sousei Hall) for the MALLS (THF) and DLS measurements.

Supplementary Information. Possible repeating units of polymer $4 ;{ }^{13} \mathrm{C}$ NMR spectra of polymer 4 and polymer 6 in $\mathrm{CDCl}_{3}$; Demonstration pictures of the formation of gold particles using polymer 3 (entry 8); Dynamic light scattering (DLS) measurements of Au particles; C-H COSY spectrum of polymer 3 (entry 8) in $\mathrm{D}_{2} \mathrm{O}$. These materials are available free of charge via the Internet. 
Table 1. The polymerization results of $\mathbf{1}$

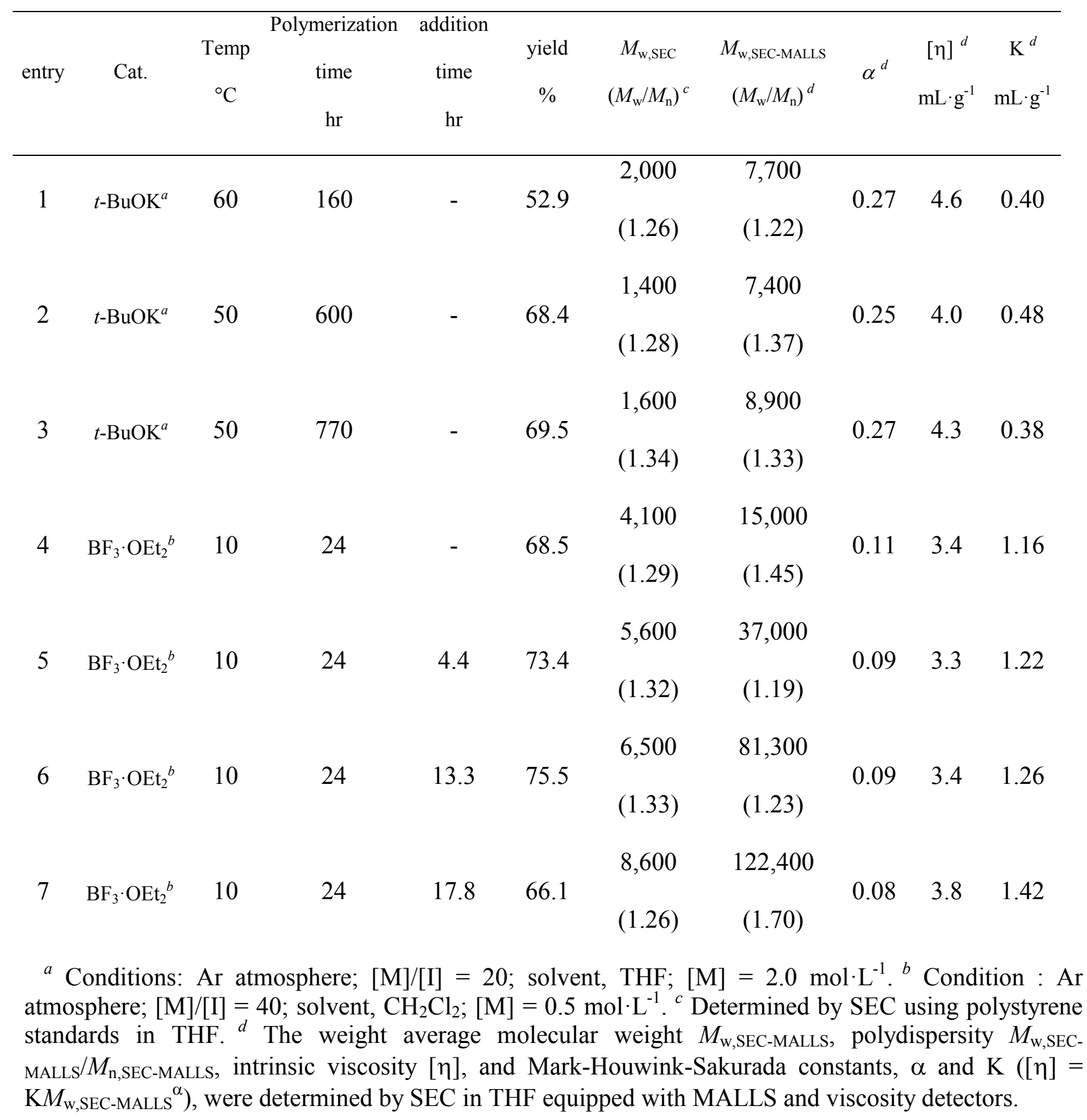


Table 2. The results of hydrolysis of $\mathbf{2}$ to prepare $\mathbf{3}$

\begin{tabular}{cccccc}
\hline & & $M_{\mathrm{w}, \text { SEC-MALLS of 3 }}{ }^{a}$ & & {$[\eta]^{a}$} & $\mathrm{~K}^{a}$ \\
& Starting Material 2 & $\alpha^{a}$ & & \\
& & $\left(M_{\mathrm{w}, \text { SEC-MALLS }} / M_{\mathrm{n}, \mathrm{SEC}-\mathrm{MALLS})}\right.$ & & $\mathrm{mL} \cdot \mathrm{g}^{-1}$ & $\mathrm{~mL} \cdot \mathrm{g}^{-1}$ \\
\hline 8 & entry 2 & & & & \\
\hline 9 & entry 7 & $3,740(1.26)$ & 0.36 & 4.4 & 0.22 \\
& & & & & \\
& & $74,400(2.74)$ & 0.26 & 5.0 & 0.29
\end{tabular}

$a$ The weight average molecular weight $M_{\mathrm{w}, \mathrm{SEC}-\mathrm{MALLS}}$, polydispersity $M_{\mathrm{w}, \mathrm{SEC}-\mathrm{MALLS}} / M_{\mathrm{n}, \mathrm{SEC}-\mathrm{MALLS}}$, intrinsic viscosity [ $\eta$, and Mark-Houwink-Sakurada constants, $\alpha$ and $\mathrm{K}\left([\eta]=\mathrm{K} M_{\mathrm{w}, \mathrm{SEC}-\mathrm{MALLS}}{ }^{\alpha}\right)$, were determined by SEC in $0.2 \mathrm{~mol} \cdot \mathrm{L}^{-1} \mathrm{NaNO}_{3}$ aqueous solution equipped with MALLS and viscosity detectors. 


\section{References}

1 C. J. Hawker and W. Devonport, ACS Symp. Ser., 1996, 624, 186.

2 J. M. J. Fréchet, C. J. Hawker, I. Gitsov and J. W. Leon, J. Macromol. Sci., Chem., 1996, A33, 1399.

3 F. Zeng and S. C. Zimmerman, Chem. Rev., 1997, 97, 1681.

4 O. A. Matthews, A. N. Shipway and J. F. Stoddart, Prog. Polym. Sci., 1998, $23,1$.

5 Y. H. Kim, J. Polym. Sci., Part A: Polym. Chem., 1998, 36, 1685.

6 A. Hult, M. Johansson and E. Malmström, Adv. Polym. Sci., 1999, 143, 1.

7 M. Fischer and F. Vogtle, Angew. Chem., Int. Ed. Engl., 1999, 38, 884.

8 B. Voit, J. Polym. Sci., Part A: Polym. Chem., 2000, 38, 2505.

9 F. Vogtle, S. Gestermann, R. Hesse, H. Schwierz and B. Windisch, Prog. Polym. Sci., 2000, $25,987$.

10 K. Inoue, Prog. Polym. Sci., 2000, 25, 453.

11 N. Hadjichristidis, M. Pitsikalis, S. Pispas and H. Iatrou, Chem. Rev., 2001, 101, 3747.

12 M. Jikei and M.-A. Kakimoto, Prog. Polym. Sci., 2001, 26, 1233.

13 H. Frey and R. Haag, Rev. Mol. Biotechnol., 2002, 90, 257.

14 S.-E. Stiriba, H. Frey and R. Haag, Angew. Chem., Int. Ed. Engl., 2002, 41, 1329.

15 F. O. H. Pirrung, E. M. Loen and A. Noordam, Macromol. Symp., 2002, 187, 683.

16 W. B. Turnbull and J. F. Stoddart, Rev. Mol. Biotechnol., 2002, 90, 231.

17 H. Frey and R. Haag, Rev. Mol. Biotechnol., 2002, 90, 257.

18 D. A. Tomalia and J. M. J. Fréchet, J. Polym. Sci., Part A: Polym. Chem., 2002, 40, 2719. 
19 I. Gitsov and K. R. Lambrych, Dendrimers. Synthesis and Applications., in Microspheres, Microcapsules \& Liposomes, ed. R. Arshady, Citus Books, London, 2002, vol. 5, pp. 31-68.

20 S. Hecht, J. Polym. Sci., Part A: Polym. Chem., 2003, 41, 1047.

21 K. Ishizu, K. Tsubaki, A. Mori and S. Uchida, Prog. Polym. Sci., 2003, 28, 27.

22 C. Gao and D. Yan, Prog. Polym. Sci., 2004, 29, 183.

23 A. Hirao, M. Hayashi, S. Loykulnant, K. Sugiyama, S. W. Ryu, N. Haraguchi, A. Matsuo and T. Higashihara, Prog. Polym. Sci., 2005, 30, 111.

24 B. D. Mather, K. Viswanathan, K. M. Miller and T. E. Long, Prog. Polym. Sci., 2006, 31, 487.

25 X. Feng, D. Taton, R. Borsali, E. L. Chaikof and Y. Gnanou, J. Am. Chem. Soc., 2006, 128, 11551.

26 N. Hadjichristidis, H. Iatrou, M. Pitsikalis and J. Mays, Prog. Polym. Sci., 2006, 31, 1068.

27 T. Satoh, M. Tamaki, Y. Kitajyo, T. Maeda, H. Ishihara, T. Imai, H. Kaga and T. Kakuchi, J. Polym. Sci., Part A: Polym. Chem., 2006, 44, 406.

28 A. Hirao, K. Sugiyama and H. Yokoyama, Prog. Polym. Sci., 2007, 32, 1393.

29 Y. Kitajyo, T. Imai, Y. Sakai, M. Tamaki, H. Tani, K. Takahashi, A. Narumi, H. Kaga, N. Kaneko, T. Satoh and T. Kakuchi, Polymer, 2007, 48, 1237.

30 Y. Kitajyo, Y. Nawa, M. Tamaki, H. Tani, K. Takahashi, H. Kaga, T. Satoh and T. Kakuchi, Polymer, 2007, 48, 4683.

31 S. Peleshanko and V. V. Tsukruk, Prog. Polym. Sci., 2008, 33, 523.

32 T. Satoh, Soft Matter, 2009, 5, 1972.

33 K. L. Wooley, J. M. J. Fréchet and C. J. Hawker, Polymer, 1994, 35, 4489. 
34 C. Schipp, M. J. Hill, P. J. Barham, V. M. Cloke, J. S. Higgins and L. Oiarzabalt, Polymer, 1996, 37, 2291.

35 C. J. Hawker, E. Malmström, C. W. Frank and J. P. Kampf, J. Am. Chem. Soc., 1997, 119, 9903.

36 M. W. Weimer, J. M. J. Fréchet and I. Gitsov, J. Polym. Sci., Part A: Polym. Chem., 1998, 36, 955.

37 P. G. Santangelo and C. M. Roland, Macromolecules, 1999, 32, 1972.

38 J.-I. Kadokawa, H. Tagaya and K. Chiba, Polym. Drugs Drug Delivery Syst., 2001, 251.

39 S.-E. Stiriba, H. Kautz and H. Frey, J. Am. Chem. Soc., 2002, 124, 9698.

40 M. Ballauff and C. N. Likos, Angew. Chem. Int. Ed., 2004, 43, 2998.

41 K. R. Kumar and D. E. Brooks, Macromol. Rapid Commun., 2005, 26, 155.

42 F. Samadi, J. Eckelt, B. A. Wolf, F.-J. Lopez-Villanueva and H. Frey, European Polym. J., 2007, 43, 4236.

43 Y. Kitajyo, Y. Kinugawa, M. Tamaki, H. Kaga, N. Kaneko, T. Satoh and T. Kakuchi, Macromolecules, 2007, 40, 9313.

44 Y. Haba, C. Kojima, A. Harada and K. Kono, Angew. Chem. Int. Ed., 2007, 46, 234.

45 Y. Chi, S. T. Scroggins and J. M. J. Fréchet, J. Am. Chem. Soc., 2008, 130, 6322.

46 S. Javor, A. Natalello, S. M. Doglia and J.-L. Reymond, J. Am. Chem. Soc., 2008, 130, 17248.

47 K. Aoi, K. Itoh and M. Okada, Macromolecules, 1995, 28, 5391.

48 K. Aoi, K. Tsutsumiuchi, A. Yamamoto and M. Okada, Tetrahedron, 1997, 53,15415.

49 K. Aoi, K. Tsutsumiuchi, A. Yamamoto and M. Okada, Macromol. Rapid Commun., 1998, $19,5$.

50 D. Zanini and R. Roy, J. Org. Chem., 1998, 63, 3486. 
51 P. R. Ashton, E. F. Hounsell, N. Jayaraman, T. M. Nilsen, N. Spencer, J. F. Stoddart and M. Young, J. Org. Chem., 1998, 63, 3429.

52 H. W. I. Peerlings, S. A. Nepogodiev, J. F. Stoddart and E. W. Maijer, Eur. J. Org. Chem., 1998, 1879.

53 K. Tsutsumiuchi, K. Aoi and M. Okada, Polym. J., 1999, 31, 935.

54 S. André, P. J. C. Ortega, M. A. Perez, R. Roy and H.-J. Gabius, Glycobiology, 1999, 9, 1253.

55 J. J. Lundquist and E. J. Toone, Chem. Rev., 2002, 102, 555.

56 S. M. Rele, W. Cui, L. Wang, S. Hou, G. Barr-Zarse, D. Tatton, Y. Gnanou, J. D. Esko and E. L. Chaikof, J. Am. Chem. Soc., 2005, 127, 10132.

57 H. Baigude, K. Katsuraya, S. Tokunaga, N. Fujiwara, M. Satoyama, T. Magome, K. Okuyama, G. Borjihan and T. Uryu, J. Polym. Sci. Part A: Polym. Chem., 2005, 43, 2195.

58 A. Takasu, T. Makino and T. Hirabayashi, J. Polym. Sci. Part A: Polym. Chem., 2009, 47, 310.

59 B. W. Greatrex, S. J. Brodie, R. H. Furneaux, S. M. Hook, W. T. McBurney, G. F. Painter, T. Rades and P. M. Rendle, Tetrahedron, 2009, 65, 2939.

60 N. Jayaraman, S. A. Nepogodiev and J. F. Stoddart, Chem. Eur. J., 1997, 3, 1193.

61 B. Colonna, V. D. Harding, S. A. Nepogodiev, F. M. Raymo, N. Spencer and J. F. Stoddart, Chem. Eur. J., 1998, 4, 1244.

62 W. B. Turnbull, A. R. Pease and J. F. Stoddart, ChemBioChem, 2000, 1, 70.

63 W. B. Turnbull, S. A. Kalovidouris and J. F. Stoddart, Chem. Eur. J., 2002, 8, 2988.

64 C. D. Heidecke and T. K. Lindhorst, Chem. Eur. J., 2007, 13, 9056. 
65 J. Bernard, A. Favier, L. Zhang, A. Nilasaroya, T. P. Davis, C. Barner-Kowollik and M. H. Stenzel, Macromolecules, 2005, 38, 5475.

66 J. Bernard, X. Hao, T. P. Davis, C. Barner-Kowollik and M. H. Stenzel, Biomacromolecules, 2006, 7, 232.

67 A. Narumi, S. Yamane, Y. Miura, H. Kaga, T. Satoh and T. Kakuchi, J. Polym. Sci., Part A: Polym. Chem., 2005, 43, 4373.

68 A. Narumi, H. Kaga, Y. Miura, T. Satoh, N. Kaneko and T. Kakuchi, Polymer, 2006, 47, 2269.

69 A. Narumi, H. Kaga, Y. Miura, I. Otsuka, T. Satoh, N. Kaneko and T. Kakuchi, Biomacromolecules, 2006, 7, 1496.

70 A. Narumi and T. Kakuchi, Polymer J., 2008, 40, 383.

71 J.-I. Kadokawa, M. Sato, M. Karasu, H. Tagaya and K. Chiba, Angew. Chem., Int. Ed., 1998, 37, 2373.

72 A. Kanazawa, S. Okumura and M. Suzuki, Org. Biomol. Chem., 2005, 3, 1746.

73 S. Muthukrishnan, G. Jutz, X. Andre, H. Mori and A. H. E. Müller, Macromolecules, 2005, 38, 9.

74 S. Muthukrishnan, H. Mori and A. H. E. Müller, Macromolecules, 2005, 38, 3108.

75 S. Muthukrishnan, F. Plamper, H. Mori and A. H. E. Müller, Macromolecules, 2005, 38, 10631.

76 A. Kanazawa and M. Suzuki, Polymer, 2006, 47, 176.

77 T. Satoh, T. Imai, H. Ishihara, T. Maeda, Y. Kitajyo, A. Narumi, H. Kaga, N. Kaneko and T. Kakuchi, Macromolecules, 2003, 36, 6364.

78 T. Imai, T. Satoh, H. Kaga, N. Kaneko and T. Kakuchi, Macromolecules, 2003, 36, 6359.

79 T. Imai, T. Satoh, H. Kaga, N. Kaneko and T. Kakuchi, Macromolecules, 2004, 37, 3113. 

Macromol. Symp., 2004, 217, 39.

81 T. Imai, Y. Nawa, Y. Kitajyo, T. Satoh, H. Kaga, N. Kaneko and T. Kakuchi, Macromolecules, $2005,38,1648$.

82 T. Satoh, T. Imai, H. Ishihara, T. Maeda, Y. Kitajyo, Y. Sakai, H. Kaga, N. Kaneko, F. Ishii and T. Kakuchi, Macromolecules, 2005, 38, 4202.

83 T. Satoh and T. Kakuchi, Macromol. Biosci., 2007, 7, 999.

84 T. Uryu, K. Kitano and K. Matsuzaki, Makromol. Chem., 1979, 180, 1135.

85 T. Uryu, K. Kitano, H. Tachikawa, K. Ito and K. Matsuzaki, Makromol. Chem., 1978, 179, 1773.

86 T. Soler, A. Bachki, L. R. Falvello, F. Foubelo and M. Yus, Tetrahedron: Asymmetry, 2000, $11,493$.

87 A. Sunder, R. Hanselmann and H. Frey, Macromolecules, 1999, 32, 4240.

88 A similar polymerization tendency was reported by Uryu et al. ${ }^{84,85}$

89 The chemical shifts of the carbons for $\alpha$ - and $\beta$-D-glucopyranoses in $\mathrm{D}_{2} \mathrm{O}$ are 93.18 and $97.00 \mathrm{ppm}$, respectively.

90 G. Just and D. Crosilla, Can. J. Chem.,1980, 58, 2349. The chemical shifts of the protons for 3,5,6tri- $O$-methyl $\alpha$ - and $\beta$-D-glucofranoses in $\mathrm{CDCl}_{3}$ are 5.40 and $5.10 \mathrm{ppm}$, respectively. Based on the ${ }^{1} \mathrm{H}$ NMR data of 3,5,6-tri- $O$-methyl $\alpha$ - and $\beta$-D-glucofranoses and $\mathrm{CH}$-COSY spectrum of polymer 3 (entry 8) in Fig. S5 (see Supplementary Information), the signals at 97.30 and 102.94 ppm in Fig. 11a are assigned to the carbons of the $\alpha$ - and $\beta$-D-glucofranose units in $\mathbf{3}$, respectively.

91 J. Liu, G. Qin, P. Raveendran and Y. Ikushima, Chem. Eur. J., 2006, 12, 2131.

92 K. Nakamura, T. Kawabata, Y. Mori, Powder Technol., 2003, 131, 120. 
93 In run 3 using the high molecular weight polymer 3 (entry 9), the intensity at $\lambda_{\max }$ is consistently rather weaker compared to run 1 using the low molecular weight sample (entry 8), probably because the sugar units on the peripheries of polymer $\mathbf{3}$ at the same unit-mol concentration is less for the high molecular weight polymer than the low molecular weight polymer, i.e., the inner sugar units of the high molecular weight polymer cannot effectively be utilized as a reductant because of the sugar units in the enclosed space.

94 The final intensity at $\lambda_{\max }$ for the $\mathrm{D}$-glucose-HAuCl $\mathrm{H}_{4}$ system was greater than those for the 3$\mathrm{HAuCl}_{4}$ system at the same mol concentration. The main factor is attributed to the links between the sugar units in $\mathbf{3}$, which cannot act as a reductant.

95 K. Esumi, T. Hosoya, A. Suzuki and K. Torigoe, J. Colloid Interface Sci., 2000, 226, 346. 
Supplementary Material (ESI) for Polymer Chemistry

Supplementary Information for:

\title{
Hyperbranched 5,6-Glucan as Reducing Sugar ball
}

\author{
Masaki Tamaki, Tsukasa Taguchi, Soichi Nakabayashi, Kota Mori, Yoshikazu Kitajyo, Ryosuke \\ Sakai, Toyoji Kakuchi, and Toshifumi Satoh*
}

Division of Biotechnology and Macromolecular Chemistry, Graduate School of Engineering, Hokkaido University, Sapporo 060-8628, Japan

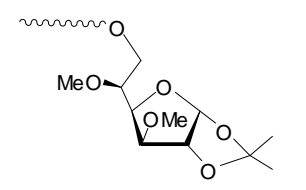

6-linked terminal unit

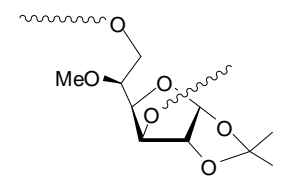

3,6-linked linear unit

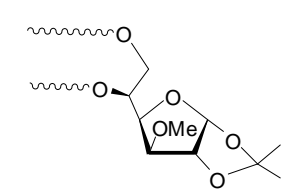

5,6-linked linear unit

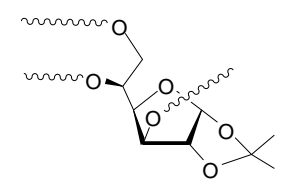

3,5,6-linked dendritic unit

Fig. S1. Possible repeating units in polymer 4. 


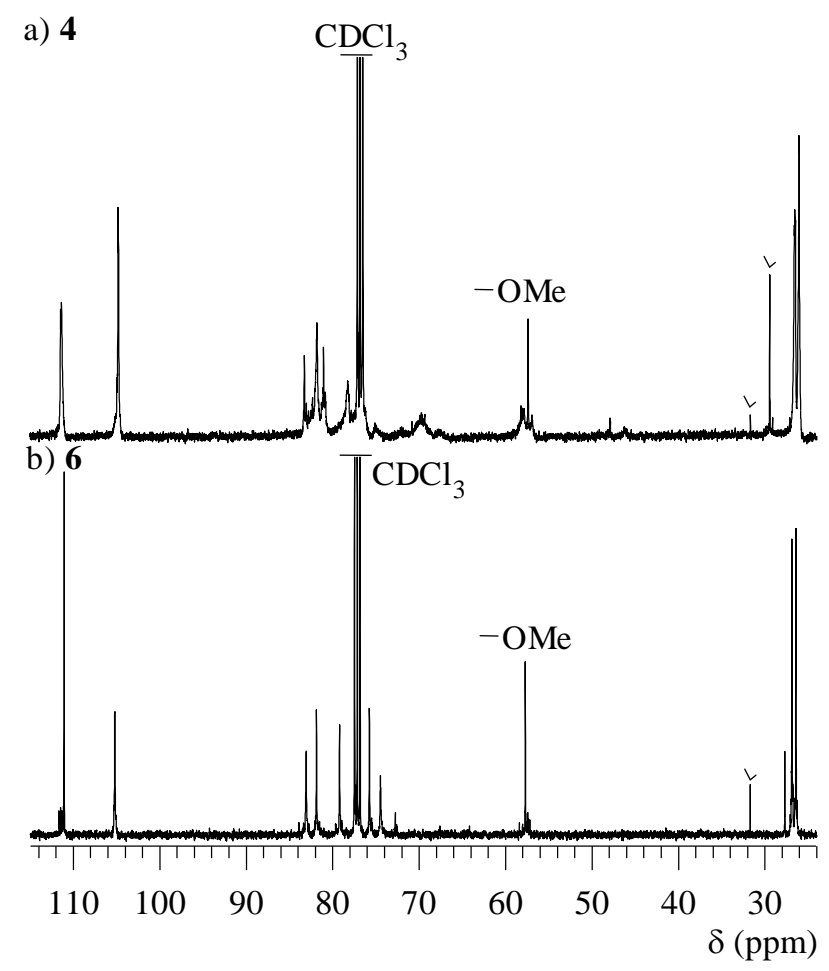

Fig. S2. ${ }^{13} \mathrm{C}$ NMR spectra of a) polymer 4 and b) polymer $\mathbf{6}$ in $\mathrm{CDCl}_{3}$ (TMS as internal standard).

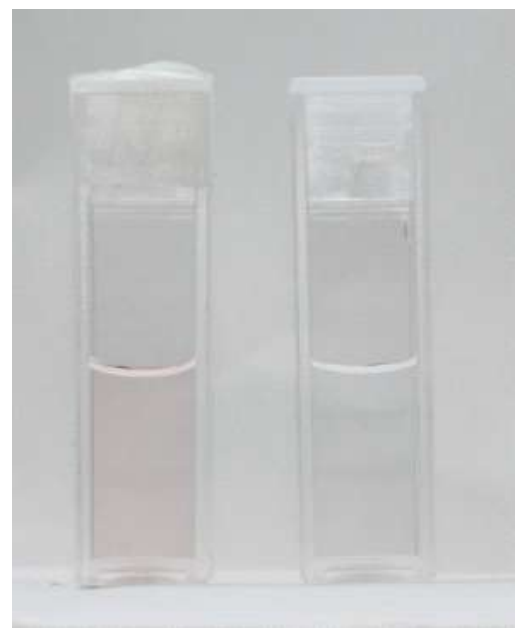

Fig. S3. Demonstration (run 1 in Fig 14) of the formation of gold particles using polymer 3 (entry 8). The left vial contains polymer $3\left(46\right.$ unit-mmol. $\left.\mathrm{L}^{-1}, 1.8 \mathrm{~mL}\right)$ and $\mathrm{HAuCl}_{4}$ aqueous solution $\left(0.01 \mathrm{~mol} \cdot \mathrm{L}^{-1}\right.$, 
$6.67 \mu \mathrm{L}$ ) at $70{ }^{\circ} \mathrm{C}$ (after 150-min mixing), while the right vial is the control experiment in the absence of polymer 3.
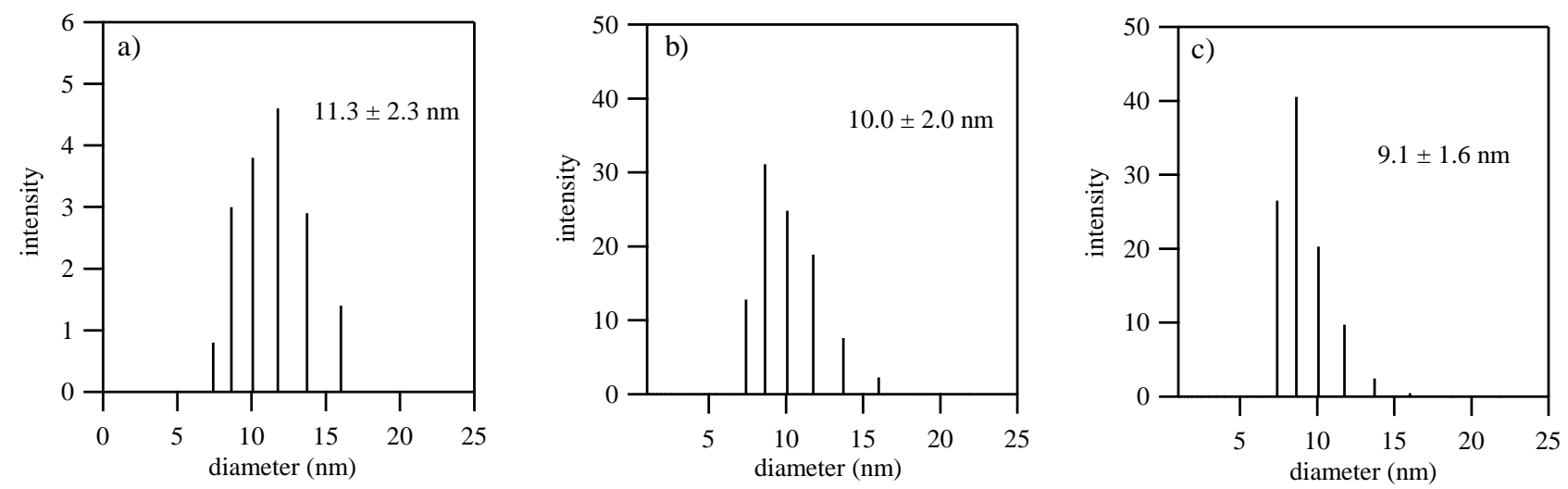

Fig. S4. Particle size distribution and average hydrodynamic diameter estimated by dynamic light scattering (DLS) measurements of run 2 in Fig 14. a) scatter average hydrodynamic diameter, b) weight average hydrodynamic diameter, and c) number average hydrodynamic diameter calculated using the histogram methods including the Marquadt analysis. 


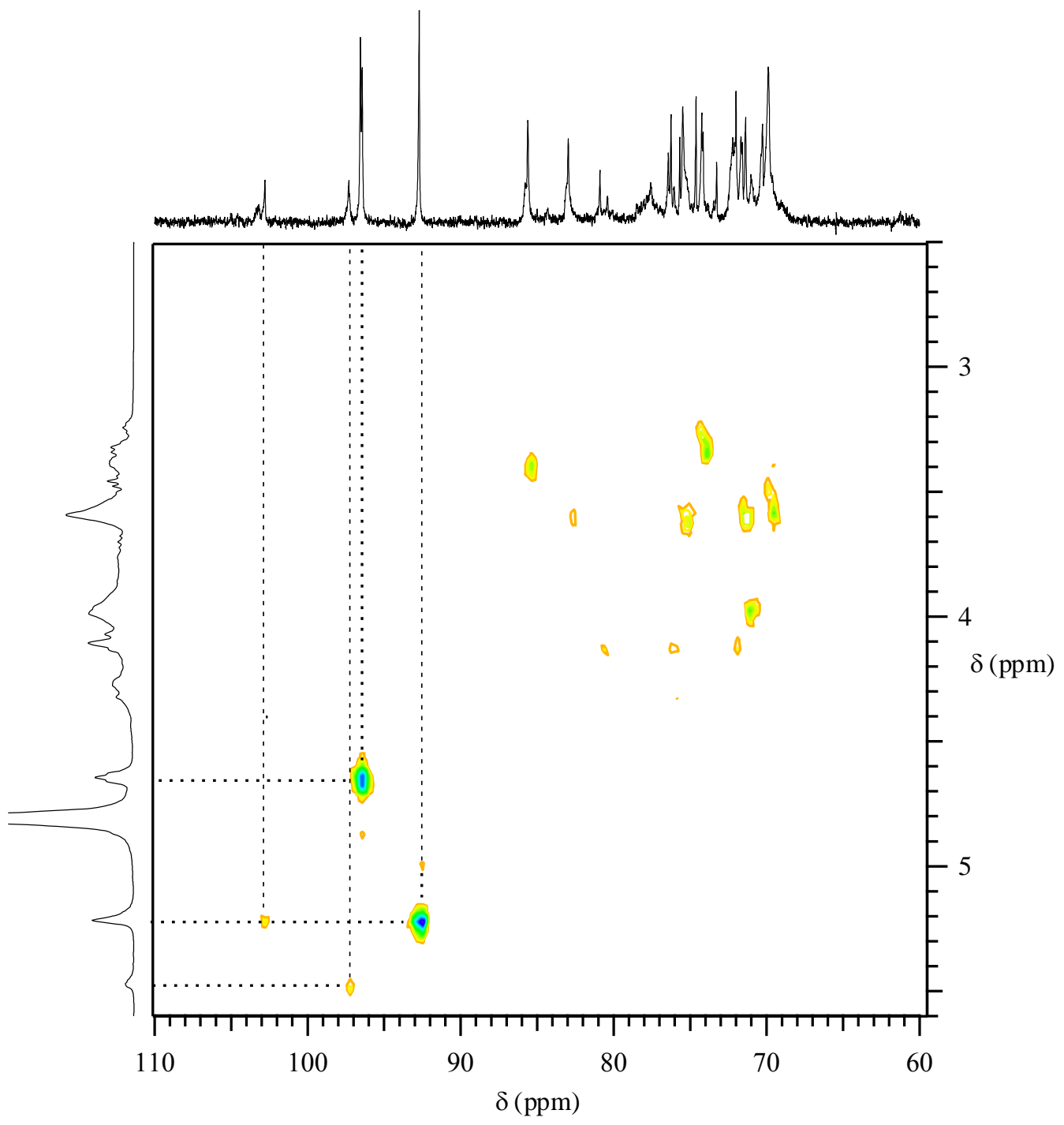

Fig. S5. C-H COSY spectrum of polymer 3 (entry 8) in $\mathrm{D}_{2} \mathrm{O}$ (acetone as internal standard). 